\title{
Nitrogen dynamics in a small arctic watershed: retention and downhill movement of ${ }^{15} \mathrm{~N}$
}

\author{
Yuriko Yano, ${ }^{1,3}$ Gaius R. Shaver, ${ }^{1}$ Anne E. Giblin, ${ }^{1}$ Edward B. Rastetter, ${ }^{1}$ and Knute J. Nadelhoffer ${ }^{2}$ \\ ${ }^{1}$ Ecosystems Center, Marine Biological Laboratory, Woods Hole, Massachusetts 02543 USA \\ ${ }^{2}$ Department of Ecology and Evolutionary Biology, University of Michigan, Ann Arbor, Michigan 48109 USA
}

\begin{abstract}
We examined short- and long-term nitrogen (N) dynamics and availability along an arctic hillslope in Alaska, USA, using a stable isotope of nitrogen $\left({ }^{15} \mathrm{~N}\right)$, as a tracer. Tracer levels of ${ }^{15} \mathrm{NH}_{4}{ }^{+}$were sprayed once onto the tundra at six sites in four tundra types: heath (crest), tussock with high and low water flux (mid- and footslope), and wet sedge (riparian). ${ }^{15} \mathrm{~N}$ in vegetation and soil was monitored to estimate retention and loss over a 3year period.

Nearly all ${ }^{15} \mathrm{NH}_{4}^{+}$was immediately retained in the surface moss-detritus-plant layer, and $>57 \%$ of the ${ }^{15} \mathrm{~N}$ added remained in this layer at the end of the second year. Organic soil was the second largest ${ }^{15} \mathrm{~N}$ sink. By the end of the third growing season, the moss-detritus-plant layer and organic soil combined retained $\geq 87 \%$ of the ${ }^{15} \mathrm{~N}$ added except at the Midslope site with high water flux, where recovery declined to $68 \%$. At all sites, non-extractable and nonlabile-N pools were the principal sinks for added ${ }^{15} \mathrm{~N}$ in the organic soil.

Hydrology played an important role in downslope movement of dissolved ${ }^{15} \mathrm{~N}$. Crest and Midslope with high-water-flux sites were most susceptible to ${ }^{15} \mathrm{~N}$ losses via leaching, perhaps because of deep permeable mineral soil (crest) and high water flow (Midslope with high water flux). Late spring melt season also resulted in downslope dissolved- ${ }^{15} \mathrm{~N}$ losses, perhaps because of an asynchrony between $\mathrm{N}$ release into melt water and soil immobilization capacity. We conclude that separation of the rooting zone from the strong sink for incoming $\mathrm{N}$ in the mossdetritus-plant layer, rapid incorporation of new $\mathrm{N}$ into relatively recalcitrant-soil- $\mathrm{N}$ pools within the rooting zone, and leaching loss from the upper hillslope would all contribute to the strong N-limitation of this ecosystem. An extended snow-free season and deeper depth of thaw under warmer climate may significantly alter current $\mathrm{N}$ dynamics in this arctic ecosystem.
\end{abstract}

Key words: arctic tundra watershed; downhill transport of nitrogen; hydrolyzable amino acids; hydrolyzable amino sugars; mosses; $N$ dynamics; $N$ immobilization; $N$ leaching; $N$ limitation; snowmelt; total dissolved $N$.

\section{INTRODUCTION}

Productivity of arctic ecosystems is strongly nitrogen (N) limited, despite very large stocks of organic $\mathrm{N}$ in soils (Jonasson et al. 1999, Shaver et al. 2001). Many past studies have indicated that the overall $\mathrm{N}$ limitation of productivity in these systems is due to slow $\mathrm{N}$ turnover in soils (e.g., Weintraub and Schimel 2005). These studies consistently find that net $\mathrm{N}$ mineralization during the growing season is lower than the annual plant $\mathrm{N}$ uptake requirement in Alaskan tundra ecosystems (e.g., Marion et al. 1987, Giblin et al. 1991, Nadelhoffer et al. 1991, Schmidt et al. 2002). Nitrogen fixation may account for as much as $76-90 \%$ of total annual $\mathrm{N}$ inputs in arctic tundra ecosystems (Hobara et al. 2006), but it is not sufficient to fill this apparent gap between plant requirement and mineralization.

Manuscript received 24 April 2008; revised 18 June 2009; accepted 10 July 2009. Corresponding Editor: R. D. Evans.

${ }^{3}$ Present address: Municipality of Anchorage, Health and Human Services, 825 L Street, Anchorage, Alaska 99501 USA. E-mail: Yuriko.Yano@gmail.com
The seasonal downslope movement of dissolved $\mathrm{N}$ in relation to the timing of plant uptake has received little attention. The importance of dissolved- $\mathrm{N}$ losses is increasingly recognized for many terrestrial ecosystems (Vitousek et al. 1998, Stepanauskas et al. 2000, Perakis and Hedin 2002, Kawahigashi et al. 2004, Rastetter et al. 2004, 2005). Rastetter et al. (2004) simulated downslope $\mathrm{N}$ movement in soil water in tundra and found that it influenced the timing and spatial pattern of responses to changes in $\mathrm{CO}_{2}$ and climate. However, few studies have demonstrated the links among the temporal and spatial variations in soil-N cycling (e.g., immobilization, mineralization), hydrology, and plant uptake along a hill slope of an arctic watershed.

Because arctic tundras are generally underlain by continuous permafrost, there is no deep leaching, and soil water must move laterally down hillslopes near the soil surface. The largest hydrological event in these ecosystems is the spring snowmelt when the largest solute losses, including N, occur (Everett et al. 1989). However, because the soil is still frozen, $\mathrm{N}$ released into snowmelt water may bypass uptake by microbes and 
plants as well as nonbiological sorption in soil, resulting in large $\mathrm{N}$ losses from the system.

We added an enriched ${ }^{15} \mathrm{NH}_{4}{ }^{+}$tracer at several sites along a hillslope at Imnavait Creek to better understand: (1) short- and long-term fate of inorganic $\mathrm{N}$ deposited on the tundra surface, and (2) spatial and seasonal movement of $\mathrm{N}$ along the hillslope via leaching. We chose $\mathrm{NH}_{4}{ }^{+}$over $\mathrm{NO}_{3}{ }^{-}$to minimize rapid ${ }^{15} \mathrm{~N}$ losses via denitrification. $\mathrm{NH}_{4}^{+}$is also a product of $\mathrm{N}$ fixation, which accounts for more than two thirds of total annual $\mathrm{N}$ inputs. Internal $\mathrm{N}$ cycling was examined by following the ${ }^{15} \mathrm{~N}$ tracer into plants and various soil- $\mathrm{N}$ pools over three growing seasons at the same locations as ${ }^{15} \mathrm{~N}$ addition. Nitrogen leaching down the hillslope was examined by following ${ }^{15} \mathrm{~N}$ into downslope-flow water at and farther downslope of the point of ${ }^{15} \mathrm{~N}$ addition.

We hypothesized that, within the first growing season, nearly all the added $\mathrm{N}$ would be immobilized into soils by microbes, as previously observed (Schimel and Chapin 1996, Clemmensen et al. 2008). Because turnover of microbial biomass can stabilize $\mathrm{N}$ in soil organic matter (Knicker et al. 1997, Kramer et al. 2003), we anticipated that most of the added $\mathrm{N}$ would be incorporated in organic matter and would remain unavailable to plants for several years. Additionally, because microbial cell walls are the single largest source of amino sugars (Kerley and Read 1997, Myrold 1998), we expected a large increase in ${ }^{15} \mathrm{~N}$ content of hydrolyzable amino sugar.

In the long term, we hypothesized that the major losses of the ${ }^{15} \mathrm{~N}$ from the tundra would occur via leaching during snowmelt each year at all sites along the hillslope. We expected little leaching of ${ }^{15} \mathrm{~N}$ during the growing season when plant and microbial uptake is high, and the soil volume available for chemical sorption is high. One exception would be within "water tracks" (channels of subsurface water drainage; Chapin et al. 1988) where soil water flows preferentially during the snow-free season. We expected leaching loss of ${ }^{15} \mathrm{~N}$ to be significant at these sites during the snowmelt and throughout the growing season.

\section{Methods \\ Study area and experimental sites}

The study was conducted on the east-facing slope of the Imnavait Creek watershed $\left(2.2 \mathrm{~km}^{2} ; 68^{\circ} 37^{\prime} \mathrm{N}\right.$, $149^{\circ} 18^{\prime} \mathrm{W}$ ), a small arctic watershed located $\sim 11 \mathrm{~km}$ east of Toolik Lake, on the North Slope of the Brooks Range in Alaska, USA (Fig. 1A). Annual mean temperature is about $-7^{\circ} \mathrm{C}$, and the soil is underlain by continuous permafrost in summer and completely frozen in winter (November-April; Hinzman et al. 1996). The maximum depth of thaw is greatest at crest and valley bottom, where it may exceed $1 \mathrm{~m}$. Elsewhere, depth of thaw rarely exceeds $0.5 \mathrm{~m}$. Annual mean precipitation is $350 \mathrm{~mm}$, a third of which falls as snow (Hinzman et al. 1996). The watershed has a distinct spring snowmelt period, characterized by saturation of the snowpack followed by flow of a slushy mass of snow (slush-flow) and by discharge of melted snow. Once the snowpack disappears, a major source of stream water is thawing of frozen soil (soilmelt). Nutrient discharge in streams peaks during snowmelt and approaches baseline levels during soilmelt; plant uptake is minimal until the soil thaws. Historically, snowmelt occurs between early May and late June (Hinzman et al. 1996).

The vegetation and soils along the hillslope follow a typical North Slope toposequence (Walker and Walker 1996), including a dry, well-drained heath tundra at the crest, relatively well-drained but mesic tussock tundra interspersed with wet water tracks on the hillslope, and a wet-sedge tundra at the riparian zone (Fig. 1B). Water tracks are visually recognizable areas of greater soil water flux with higher density of shrub species and intermittent surface water flow. Detailed description of water tracks is found in Chapin et al. (1988). On a hillslope $\sim 1 \mathrm{~km}$ south (upstream) of a gauging station on Imnavait Creek, six experimental sites were established, each site containing two treatment plots. They were heath tundra on crest (Crest), non-water track and water track tussock tundra on midslope (Midslope_NWT, Midslope_WT), non-water track and water track tussock tundra on footslope (Footslope_NWT, Footslope_WT), and wet-sedge tundra on riparian zone (Riparian; Fig. 1B). There were two replicate treatment plots $(n=2)$ on each site (i.e., $2 \times 6=$ total of 12 plots), and each plot was $3 \times 6 \mathrm{~m}$ in area.

Nitrogen fixation, which may account for as much as $76-90 \%$ of total annual $\mathrm{N}$ inputs, was significant only near the soil surface $(0-3 \mathrm{~cm})$, and fixation rates within this watershed were similar across the toposequence at $\sim 80 \mathrm{mg} \cdot \mathrm{m}^{-2} \cdot \mathrm{yr}^{-1}$ (Hobara et al. 2006). The activity of denitrification enzyme was higher for soil cores collected from the riparian zone than from the crest (AlexanderOzinskas 2008).

\section{${ }^{15} \mathrm{~N}$ addition}

On 5 July 2003, we added $\left({ }^{15} \mathrm{NH}_{4}\right)_{2} \mathrm{SO}_{4}$ dissolved in Imnavait Creek water to each plot at $3.92 \mathrm{mmol} / \mathrm{m}^{2}$ using backpack sprayers. This amount was $<0.006 \%$ of the annual $\mathrm{N}$ requirement for plant uptake in tussock tundra (Shaver and Chapin 1991). The total nitrogen concentration in creek water was very low (total dissolved $\mathrm{N}<23 \mu \mathrm{M}$ ), so no corrections for the ${ }^{15} \mathrm{~N}$ from creek water were made. Each ${ }^{15} \mathrm{~N}$-addition plot served as an experimental unit for ${ }^{15} \mathrm{~N}$ recovery in the vegetation, soil, soil extracts, and soil-pore water. For water flowing downhill, each experimental unit included the area directly below the plot (Fig. 1B: Sampling transects for downslope-flow water).

\section{Vegetation sampling}

Prior to ${ }^{15} \mathrm{~N}$ addition, green leaves and other plant parts of the dominant species were collected from areas adjacent to the plots. The species collected included 


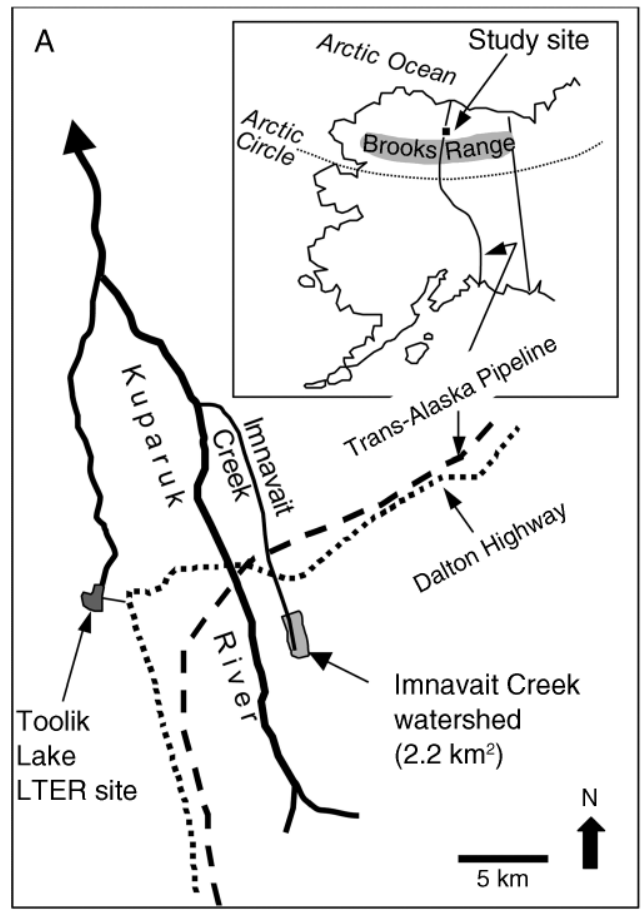

B

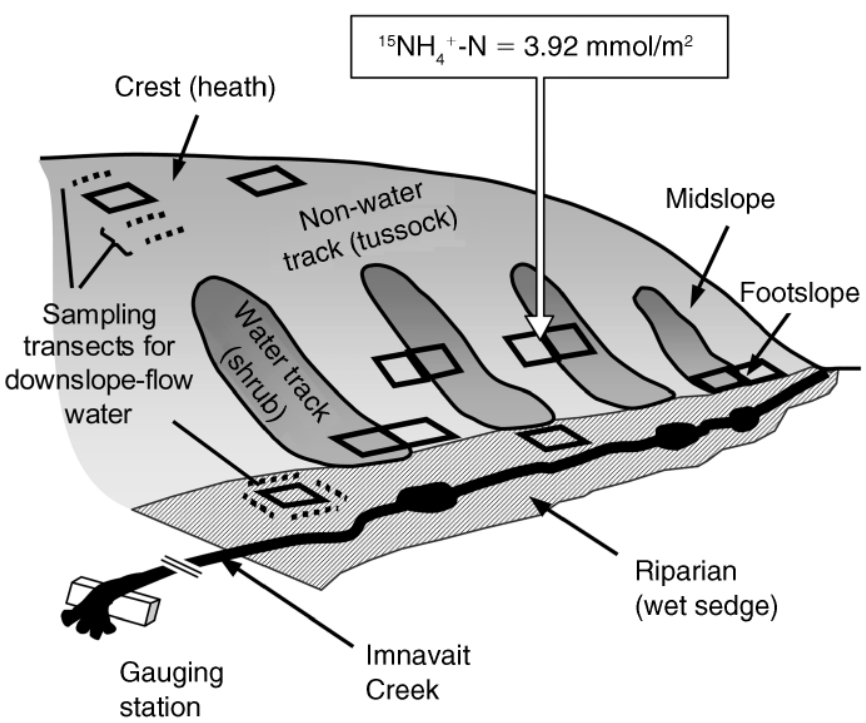

FIG. 1. Field site location at Imnavait Creek watershed, a small arctic watershed located $\sim 11 \mathrm{~km}$ east of Toolik Lake long-term ecological research site (LTER), on the North Slope of the Brooks Range in Alaska, USA: (A) a map of the field site and (B) a description of experimental design. In panel (B), each open box indicates a $3 \times 6 \mathrm{~m}$ treatment plot (i.e., experimental unit) where $\left({ }^{15} \mathrm{NH}_{4}\right)_{2} \mathrm{SO}_{4}$ was added at ${ }^{15} \mathrm{~N}=3.92 \mathrm{mmol} / \mathrm{m}^{2}$ in July 2003. Sampling transects (dotted lines) were established along the hillslope at each topolocation (distance from plots varies; for details see Methods) to determine ${ }^{15} \mathrm{~N}$ movement as dissolved $\mathrm{N}$ in water leaching downslope (downslope-flow water). Examples of transects are shown for one Crest and one Riparian plot.

deciduous shrubs (Betula nana, Salix spp.), evergreens (Vaccinium vitis-idaea), sedges (Carex spp., Eriophrum vagenatum), and mosses (Hylocomium spp., Sphagnum spp.). After the ${ }^{15} \mathrm{~N}$ addition, the same tissues were collected from within the plots 1 and 2 years later. Within $12 \mathrm{~h}$ of collection, plant samples were separated by species and tissue type and were dried at $50^{\circ} \mathrm{C}$.

\section{Soil sampling and extraction}

Five randomly located soil cores (diameter range 5-6 $\mathrm{cm})$ were collected from each plot immediately before and then 1 day, 6 days, 1 month, and 1 year after ${ }^{15} \mathrm{~N}$ addition (4, 6, and 11 July, and 5 August 2003; 12 and 14 July 2004), and four cores were collected after 2 years (16 and 20 July 2005). At each collection, cores were taken to the maximum possible depth, defined as either the full core length $(40 \mathrm{~cm})$, the bottom of the seasonally thawed "active layer," or to a rock (at Crest only). Upon collection, the length of the core was measured and the core was separated in the field into the following layers by cutting with a knife on a clean plastic sheet:

1) green layer, the surface live moss-detritus-plant layer including lichens, graminoid foliage $<2 \mathrm{~cm}$ above the ground, and ground cover species (e.g., Vaccinium vitis-idaea, Empetrum nigrum, forbs);
2) first organic layer, the upper $10 \mathrm{~cm}$ of organic soil or, if the organic layer was $<10 \mathrm{~cm}$ thick, the entire layer (e.g., there was never $>4 \mathrm{~cm}$ of organic soil at Crest);

3) second organic layer, organic soil below $10 \mathrm{~cm}$, ranging from $0 \mathrm{~cm}$ (Crest) to $17 \mathrm{~cm}$ (Riparian) thick;

4) mineral layer, the soil beneath the organic layers ranging from $0 \mathrm{~cm}$ (Riparian; organic soil extended beyond the depth of thaw) to $7 \mathrm{~cm}$ (Midslope_NWT).

The depth of soil thaw increases through the season, reaching a maximum in late July or early August. Because thaw depth is less variable spatially than the thickness of Oe and Oa horizons and our interest was in sampling water moving along the surface of the frozen soil, dividing soil cores by depth was more appropriate than by taxonomic horizons. Mean thickness of each layer and their properties are listed in the Appendix.

Within $12 \mathrm{~h}$ of collection, soil samples were weighed, homogenized, and live roots and rocks hand picked; the rocks were weighed to determine rock mass. Subsamples were dried at $50^{\circ} \mathrm{C}$ to determine moisture content. To assess recovery of ${ }^{15} \mathrm{~N}$ in water-extractable- $\mathrm{N}$ pool over time, the remaining homogenized soils were combined by plot and by layer, further homogenized, and then subsamples ( $\sim 50-100 \mathrm{~g}$, wet mass) were taken from the first and second organic layers. Within $5 \mathrm{~h}$, subsamples were added to deionized (DI) water and extracted for $8 \mathrm{~h}$ 
at $20^{\circ} \mathrm{C}$ on a shaker table. In 2003 , the ratio of wet soil to DI water was $1: 10(\mathrm{~m} / \mathrm{m})$ for the first organic layer, but was 1:5 for the second organic layer to ensure a sufficiently high $\mathrm{N}$ concentration for later analyses. A soil to water ratio of 1:10 was used for both layers in 2004 and 2005. The extractants were filtered through ashed $\mathrm{GF} / \mathrm{F}$ glass fiber filters and frozen.

We examined ${ }^{15} \mathrm{~N}$ distribution across chemically fractionated-N pools twice during our study. At 1.5 months after ${ }^{15} \mathrm{~N}$ addition in 2003, three random samples of the first organic layer were collected, pooled, and processed as just described. We chose this layer because we expected to find a larger fraction of added ${ }^{15} \mathrm{~N}$ and greater microbial activity because of higher temperatures and a longer thaw period than deeper soil layers. Within 2 days the wet soils were transferred on ice to the University of Michigan; there the soils were fractionated within 5 days of collection into salt $(0.25$ $\mathrm{mol} / \mathrm{L} \mathrm{K}_{2} \mathrm{SO}_{4}$ )-extractable dissolved N (SEDN), chloroform-fumigation-extractable $\mathrm{N}(\mathrm{CFN})$, and residual $\mathrm{N}\left(\mathrm{N}_{\text {res }}\right)$ using the method of Brookes et al. (1985). We determined ${ }^{15} \mathrm{~N}$ in these fractions using alkaline persulfate digestion (Cabrera and Beare 1993) followed by alkaline diffusion (Brooks et al. 1989). Total ${ }^{15} \mathrm{~N}$ recovery in the bulk soil was determined in ground subsamples. Because we were not certain whether the extractability coefficient $\left(K_{\mathrm{n}}\right)$ used in other studies would apply to our study site, we report CFN instead of an adjusted microbial $\mathrm{N}$ value.

We assume changes in ${ }^{15} \mathrm{~N}$ distribution across $\mathrm{CFN}$ fractions are minimal based on previous ${ }^{15} \mathrm{~N}$ labeling studies. Redistribution of $\mathrm{N}$ among soil- $\mathrm{N}$ pools following the initial assimilation was small when ${ }^{15} \mathrm{NH}_{4}{ }^{+}$was added to temperate forest soils (Perakis and Hedin 2001) or to tundra soils (Schimel and Chapin 1996). Therefore, to obtain more complete picture of $\mathrm{N}$ dynamics at Imnavait Creek, we took additional subsamples of the first organic layer in year 2 and fractionated $\mathrm{N}$ by acid hydrolysis rather than chloroform fumigation. To obtain natural ${ }^{15} \mathrm{~N}$ abundance for these fractions, six additional soil cores were collected from outside the plots and processed as just described.

\section{Sampling soil pore water}

Seven to eight days prior to ${ }^{15} \mathrm{~N}$ addition, 10 tension micro-lysimeters were installed at each plot by excavating five holes (diameter $\sim 20 \mathrm{~cm}$ ) and inserting lysimeters on the uphill-side wall of the hole at 10 and $20 \mathrm{~cm}$ depth, leaving the soil column above the lysimeters intact. The holes were backfilled and marked. Each lysimeter was individually connected to a $500-\mathrm{mL}$ high density polyethylene (HDPE) Erlenmeyer flask, and soil water was collected as described by Lajtha et al. (1999). In a preliminary study, we installed micro-lysimeters at various depths $(0-33 \mathrm{~cm})$ and topolocations near the study site and found no installation effect on the concentration of dissolved $\mathrm{N}$ after $3,4,10,15$, and 23 days (data not shown). Therefore, we purged the micro- lysimeters and allowed them to equilibrate for $\geq 5$ days prior to the first sampling. Sample collections were made on the day before ${ }^{15} \mathrm{~N}$ addition and 4 days, 1 month, and 1 year after addition. Because the void space of a microlysimeter was negligible relative to sample volume collected $(<1 \%)$, we did not purge the lysimeters prior to each sampling. However, at the beginning of each growing season, all lysimeters were purged to remove any over-winter water.

\section{Sampling snow and downslope-flow water}

Snow.-To determine snow N concentration, we collected snow cores 1-3 weeks prior to the start of slush-flow; the bottom $\sim 1 \mathrm{~cm}$ that had contact with the green layer was removed. The snow was thawed, filtered, refrozen at the field station, and shipped to Marine Biological Laboratory (MBL, Woods Hole, Massachusetts, USA) for chemical analyses. In 2004, five snow cores each were collected from five evenly spaced topolocations along the hillslope (total of 25 cores), and the samples were analyzed separately. Based on the small variability among individual samples in 2004, one core each was collected from the five topolocations (total five cores) in 2006 and all samples were combined for analysis.

Downslope-flow water during the spring melt.-In May 2004 and 2006, we collected spring melt water to determine ${ }^{15} \mathrm{~N}$ movement. Prior to snowmelt, six $6-\mathrm{m}$ sampling transects were established for each labeled plot. The transects ran perpendicular to the hillslope, located 1-5 $\mathrm{m}$ above the labeled plots and 1,2, 5, 10, or $15 \mathrm{~m}$ below the labeled plots (Fig. 1B). At Riparian, where negative grades were found toward the creek and downstream, two sets of two transects were established around the plots, one perpendicular to the creek and the other parallel to the creek (Fig. 1B). All transects at Riparian were $1 \mathrm{~m}$ from the plots. The two Riparian transects that were elevated (those on the crest and upstream sides) relative to the other two were considered as a reference, and the two below the plot were considered to be "below" the plot.

Water samples were collected using a $60-\mathrm{mL}$ syringe connected by Tygon tubing to a thin, $30 \mathrm{~cm}$ long stainless steel tube with small holes drilled within $5 \mathrm{~cm}$ from the closed tip. These samples were collected from the bottom of the thawed layer, from 3-5 random locations within the ${ }^{15} \mathrm{~N}$-addition plot and on each transect. To collect within an extremely shallow thawed layer, the sampling needle was inserted horizontally to the surface of the frozen layer. These were pooled by plot or transect in the field to make a similar final volume and processed as for other water samples.

Water collected while snow existed on the plots was called "snowmelt," and water collected after all snow on the plot had disappeared was called "soilmelt" (see Plate 1). Snowmelt collection became possible only $\sim 2$ days prior to slush-flow at the gauging station, and the snow cover disappeared completely from the entire 
hillslope within one (2006) or two (2004) weeks after the slush-flow. In 2004, we collected snowmelt samples twice, (18 or 19 May and 22 May), and soilmelt samples once (31 May). In 2006, snowmelt samples were collected on 16, 17, and 19 May and soilmelt samples on 25 May. The winter before the 2004 snowmelt was typical, whereas the winter before the 2006 snowmelt was one of the driest winters for this watershed, which has been studied since 1976. Nonetheless, the major slush-flow at the gauging station occurred on 18 May for both years (R. Giek, personal communication).

Downslope-flow water during the growing season.Downslope-flow water during the summer was collected at the bottom of the thawed active layer in the same manner as the collection of downslope-flow water during the spring melt. In 2004, samples were collected 1 day, 1 week, 1 month, and 1 year after ${ }^{15} \mathrm{~N}$ addition. Soil moisture was too low to collect water samples after long periods without rain, especially during the growing season and at the Crest site.

\section{Chemical analysis}

${ }^{15} N$ recovery in hydrolyzable- $N$ pools.-We measured the pool size and ${ }^{15} \mathrm{~N}$ recovery into three hydrolyzable labile-N pools; hydrolyzable $\mathrm{NH}_{4}{ }^{+}\left(\mathrm{HNH}_{4}{ }^{+}\right)$, amino acids (HAA), and amino sugars (HAS). Soils were thawed and five replicates $(2-10 \mathrm{~g})$ of ground samples were hydrolyzed and the hydrolysates were neutralized with $\mathrm{NaOH}$ (Mulvaney and Khan 2001). Hydrolyzable $\mathrm{NH}_{4}{ }^{+}$was determined by a hypochlorite-alkaline phenol method. To determine ${ }^{15} \mathrm{~N}$ recovery in this pool, aliquots $(\sim 10 \mu \mathrm{mol} \mathrm{N})$ of the hydrolysates were diffused in a $450-\mathrm{mL}$ Mason jar with $\mathrm{MgO}$ at $50^{\circ} \mathrm{C}$ for $6 \mathrm{~h}$ onto an acid trap according to Mulvaney and Khan (2001), but replacing their "wet" acid trap (a beaker containing $5 \mathrm{~mL}$ of $4 \% \mathrm{H}_{3} \mathrm{BO}_{3}$ ) with a "dry" acid trap (an acidified GF/D filter disc encapsulated in Teflon tape) so that $\mathrm{N}$ on the trap could be directly analyzed for ${ }^{15} \mathrm{~N}$ by isotope ratio mass spectrometry.

Concentration and ${ }^{15} \mathrm{~N}$ recovery for hydrolyzable amino sugar and amino acid were determined by a sequential diffusion of the neutralized hydrolysates. For concentration, the hydrolysate was diffused for $8 \mathrm{~h}$ into a wet acid trap, then re-diffused with a new wet acid trap for $6 \mathrm{~h}$ after converting amino acids to $\mathrm{NH}_{4}^{+}$by a ninhydrin reaction under an acidic condition (Mulvaney and Khan 2001). Both first (HAS) and second (HAA) acid traps were analyzed for $\mathrm{NH}_{4}{ }^{+}$concentration as for hydrolyzable ammonium. To determine ${ }^{15} \mathrm{~N}$ recovery in the HAS and HAA pools, aliquots of the hydrolysate $(\sim 10 \mu \mathrm{mol} N)$ were sequentially diffused with dry acid traps in place of wet traps. Because total soil $\mathrm{N}$ is a sum of hydrolyzable and non-hydrolyzable $\mathrm{N}$ (i.e., total soil $\mathrm{N}=\mathrm{HNH}_{4}{ }^{+}+\mathrm{HAS}+\mathrm{HAA}+$ hydrolyzable-unknown $\mathrm{N}$ + non-hydrolyzable $\mathrm{N}$ ), pool sizes and $\delta^{15} \mathrm{~N}$ signatures of hydrolyzable-unknown $\mathrm{N}$ and non-hydrolyzable $\mathrm{N}$ fractions combined, or non-labile $\mathrm{N}$ fraction (non-LN), were calculated by differences in $\delta^{15} \mathrm{~N}$ and mass of known $\mathrm{N}$ pools (total soil $\mathrm{N}, \mathrm{HNH}_{4}{ }^{+}$, HAS, and HAA). We are aware that some of the proteinaceous- $\mathrm{N}$ in soil may not be hydrolyzed by hot $6 \mathrm{~mol} / \mathrm{L} \mathrm{HCl}$ because of a physical protection of $\mathrm{N}$ compounds by non-hydrolyzable components, such as humic substances (Zang et al. 2000, Friedel and Scheller 2002). We assumed that HAA determined in this study is a fraction of peptidic $\mathrm{N}$ in soil that was more susceptible to degradation by extracellular enzymes in the soil than the non-hydrolyzable fraction.

${ }^{15} \mathrm{~N}$ analysis.-Following alkaline-persulfate digestion (Cabrera and Beare 1993), all solution samples were diffused onto dry traps by the method of Sigman et al. (1997) for $\delta^{15} \mathrm{~N}$ analysis. Dried vegetation and soil samples were ground to pass a $0.15-\mathrm{mm}$ screen for total $\mathrm{C}, \mathrm{N}$, and $\delta^{15} \mathrm{~N}$ analyses. All ground and diffused samples were analyzed by isotope ratio mass spectrometry at the MBL Stable Isotope Laboratory, unless noted otherwise.

DIN and DON.- In solution samples, $\mathrm{NH}_{4}{ }^{+}-\mathrm{N}$ was determined by the hypochlorite-alkaline phenol method. A Cd-reduction method was used to determine $\mathrm{NO}_{3}{ }^{-}-\mathrm{N}$ concentrations in samples collected in 2003-2005, whereas ion chromatography was used for samples collected in 2006. Nitrite in our samples was below the detection limit $(<0.2 \mu \mathrm{mol} / \mathrm{L})$. Total dissolved $\mathrm{N}$ (TDN) was determined by a persulfate digestion (modified from Solozano and Sharp 1980) followed by $\mathrm{NO}_{3}{ }^{-}$analysis. For 2005 samples, a high-temperature combustion method was used. Cross comparison of selected samples showed that the between-methods difference in measured concentration was $<5 \%$. Dissolved organic $N$ (DON) was calculated as the difference between TDN and dissolved inorganic N (DIN).

\section{Data analysis}

The physico-chemical properties of each layer were determined separately, and the mean for each layer was calculated by plot. For 1- and 2-year green layer samples, we estimated the partitioning of ${ }^{15} \mathrm{~N}$ between live mosses and non-moss compartments. First, using the $\delta^{15} \mathrm{~N}$ values of mosses within the enriched plots and the moss biomass estimates by Hahn et al. (1996) and Hastings et al. (1989), we estimated the total recovery of ${ }^{15} \mathrm{~N}$ in mosses. The non-moss component, mainly the detritus trapped in the mosses, was then calculated as a difference between total recovery in the green layer and recovery in mosses.

The recovery of added ${ }^{15} \mathrm{~N}$ in plants, the green layer, and soil, was determined as percentage ${ }^{15} \mathrm{~N}$-gain relative to background ${ }^{15} \mathrm{~N}$. The enrichment of ${ }^{15} \mathrm{~N}$ in the dissolved-N pool was expressed as ${ }^{15} \mathrm{~N}$ atom percent excess, which is the excess percentage of ${ }^{15} \mathrm{~N}$ atom percent relative to the reference level. A minimum detectable difference for ${ }^{15} \mathrm{~N}$ analysis of dissolved-N was $5 \%$ in $\delta^{15} \mathrm{~N}$ or $0.0018 \%$ in ${ }^{15} \mathrm{~N}$ atom percent excess.

To evaluate rates of changes in mobilized ${ }^{15} \mathrm{~N}$ (i.e., dissolved ${ }^{15} \mathrm{~N}$ ) along the hillslope, we estimated for 
TABLE 1. Estimated flux of surface water at each site during normal snowmelt.

\begin{tabular}{lcc}
\hline \hline \multicolumn{1}{c}{ Site } & $\begin{array}{c}\text { Approximate distance } \\
\text { from the Creek }(\mathrm{m})\end{array}$ & $\begin{array}{c}\text { Total water running over } \\
\text { tundra surface }\left(\mathrm{L} / \mathrm{m}^{2}\right)\end{array}$ \\
\hline Crest & 610 & 93 \\
Midslope & 270 & 28497 \\
Footslope & 150 & 46864 \\
Riparian & 60 & 59307 \\
\hline
\end{tabular}

Notes: Average snowpack-water equivalent for the years 1985-1990, calculated from data reported by Hinzman et al. (1996), was used to calculate the volume of runoff water (i.e., downslope-flow water). We assumed that, during the snowmelt, each site received all water in the snowpack directly above it because the frozen ground would prevent penetration of water and because little, if any, evapotranspiration would be occurring during this time. The structural differences of vegetation types across the topolocation were assumed to have little effect on the hydrology during this period.

downslope-flow waters the distance required to reduce ${ }^{15} \mathrm{~N}$ atom percent excess in the water by $50 \%$ and $95 \%$ of the level in downslope-flow water within the plots. To do so, we used linear regression to estimate the relationship between the natural $\log$ of ${ }^{15} \mathrm{~N}$ atom percent excess $(\ln [\mathrm{APE}])$ and distance from the plots for each site, then used the regression equation to calculate the distance for $50 \%$ and $95 \%$ reduction.

To estimate ${ }^{15} \mathrm{~N}$ transport along the hillslope during snowmelt in 2004 , we used our ${ }^{15} \mathrm{~N}$ atom percent excess data and snowpack-water equivalents (Table 1), which were calculated from data reported for the years 19851987 and 1989-1990 by Hinzman et al. (1996), assuming that the snowpack-water equivalents during our study were similar to the 1985-1990 mean. We assumed that each site received all melt water in the snowpack directly above it because the frozen ground would prevent penetration of water and because evapotranspiration would be negligible. We did not include data from 2006, because the 2006 winter was unusually dry with an unusually thin snowpack.

Statistical analysis was performed using SYSTAT 11.0 (2004; SYSTAT Software, Chicago, Illinois, USA). We tested the effect of sites on $\mathrm{N}$ concentrations, ${ }^{15} \mathrm{~N}$ recovery, and ${ }^{15} \mathrm{~N}$ atom percent excess at each time point or for specific time period using analysis of variance

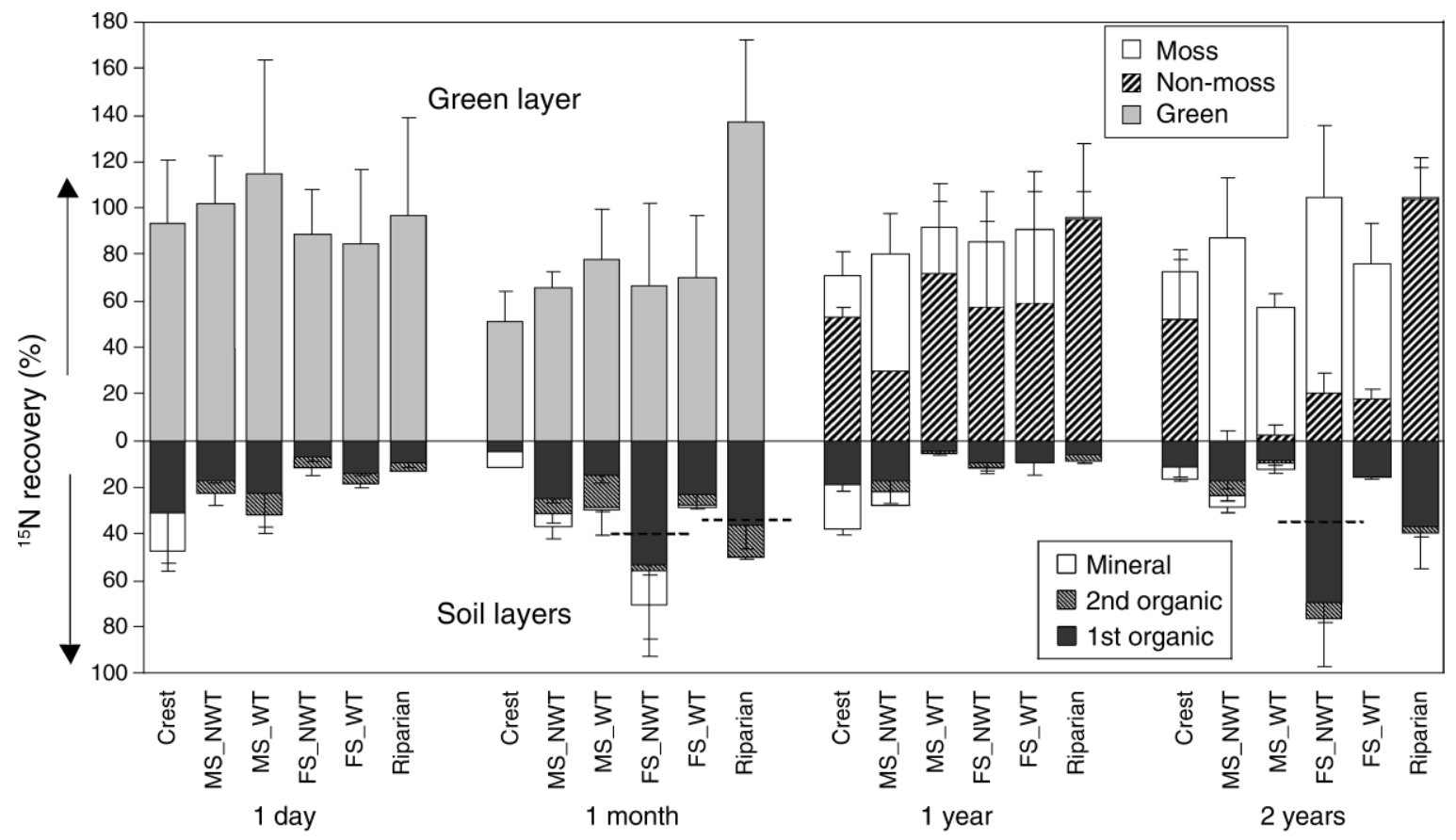

Site location and sampling time

FIG. 2. Distribution of ${ }^{15} \mathrm{~N}$ recovered in the green and soil layers during the first two years. The upper panel shows recovery in the green layer, and the lower panel shows recovery in the soil layers. The error bars show 1 SE of the mean across measurements within each site. The dashed lines in the lower panel indicate mean total recovery in soil when outliers of first organic layer were omitted. For 1- and 2-year samples, the recovery in the green layer was split into moss and non-moss components. The recovery in mosses was calculated using ${ }^{15} \mathrm{~N}$ determined for these two years and the pool size of aboveground plant $\mathrm{N}$ reported by Hahn et al. (1996) and Hastings et al. (1989). Recovery in the non-moss component, which included litter trapped in mosses and segments of vascular plants, was determined as the difference between ${ }^{15} \mathrm{~N}$ recovered in the total green layer and in the mosses only. Of the ${ }^{15} \mathrm{~N}$ recovered in the non-moss component of the green layer, little was recovered in vascular plants, i.e., vascular plants could explain $<7 \%$ of total ${ }^{15} \mathrm{~N}$ recovered in the non-moss component, even when as much as $10 \%$ of the entire aboveground vascular biomass was assumed to be found in the green layer. Abbreviations are as follows: Green, green layer; Mineral, mineral layer; 2nd organic, second organic layer; 1st organic, first organic layer; MS, Midslope; FS, Footslope; NWT, non-water tracks; WT, water tracks. Mineral, 1st organic, and 2nd organic are soil layers. For detailed description of soil layers, see the Appendix. 
TABLE 2. Effects of site on pool size and on ${ }^{15} \mathrm{~N}$ recovery for various $\mathrm{N}$ pools in the first organic layer.

\begin{tabular}{|c|c|c|c|c|c|c|c|}
\hline \multirow[b]{2}{*}{ Site } & \multicolumn{3}{|c|}{ Soil-N pool (\%) } & \multicolumn{3}{|c|}{$\begin{array}{l}\text { Contribution to }{ }^{15} \mathrm{~N} \text { recovery } \\
\text { in the first organic layer }(\%)\end{array}$} & \multirow{2}{*}{$\begin{array}{c}{ }^{15} \mathrm{~N} \text { recovered } \\
\text { in first organic } \\
\text { layer }(\%) \dagger\end{array}$} \\
\hline & SEDN & $\mathrm{CFN}$ & $\mathrm{N}_{\text {res }}$ & SEDN & $\mathrm{CFN}$ & $\mathrm{N}_{\text {res }}$ & \\
\hline Crest & $0.7(0.00)$ & $0.3(0.08)$ & $99.0^{\mathrm{ab}}(0.1)$ & $3.0(1.22)$ & $5.3(1.40)$ & $91.7(2.6)$ & $6.3(0.2)$ \\
\hline Midslope NWT & $0.8(0.33)$ & $0.8(0.14)$ & $98.5^{\mathrm{a}}(0.2)$ & $2.2(0.54)$ & $4.8(0.16)$ & $93.0(0.7)$ & $33.5(26.7)$ \\
\hline Midslope_WT & $0.7(0.21)$ & $0.3(0.24)$ & $98.9^{\mathrm{ab}}(0.0)$ & $1.8(0.89)$ & $1.5(0.68)$ & $96.7(0.2)$ & $22.6(11.0)$ \\
\hline Footslope NWT & $0.8(0.14)$ & $0.7(0.10)$ & $98.4^{\mathrm{a}}(0.0)$ & $1.7(0.59)$ & $9.0(7.34)$ & $89.3(6.8)$ & $27.7(12.7)$ \\
\hline Footslope_WT & $0.7(0.13)$ & $0.2(0.09)$ & $99.0^{\mathrm{ab}}(0.0)$ & $1.1(0.10)$ & $3.7(1.32)$ & $95.1(1.2)$ & $32.6(10.2)$ \\
\hline Riparian & $0.4(0.26)$ & $0.2(0.13)$ & $99.4^{\mathrm{b}}(0.4)$ & $2.5(0.72)$ & $0.1(1.01)$ & $97.3(0.3)$ & $17.1(1.1)$ \\
\hline
\end{tabular}

Notes: Soils were collected from within the plots in mid August 2003 (1.5 mo since ${ }^{15} \mathrm{~N}$ addition). Significant differences at $P<$ 0.05 are indicated by the superscript letters and refer to one-way ANOVA for N pools. The values in the parentheses are standard errors $(n=2)$ of measurement. Abbreviations are as follows: NWT, non-water track; WT, water track; SEDN, salt $(0.25 \mathrm{~mol} / \mathrm{L}$ $\mathrm{K}_{2} \mathrm{SO}_{4}$ )-extractable $\mathrm{N}$; $\mathrm{CFN}$, chloroform-fumigation-extractable $\mathrm{N} ; \mathrm{N}_{\text {res }}$, non-extractable residual $\mathrm{N}$. Note that $\mathrm{CFN}$ values are not corrected for the extraction factor $\left(K_{\mathrm{n}}\right)$ commonly used to estimate microbial biomass $\mathrm{N}$.

$\dagger$ Total recovery of ${ }^{15} \mathrm{~N}$ within the first organic layer (as percentage of amount added).

(ANOVA), followed by multiple comparisons using a least significant difference (LSD) test and a significance level of $P<0.05$. When necessary, data were natural-log or square-root transformed prior to statistical analysis to obtain similar distribution and variance across sites.

Our attempt to accomplish a detailed characterization of temporal as well as spatial $\mathrm{N}$ dynamics along the complete hillslope required some compromises on sample replication and on the suite of analyses conducted simultaneously. Low replication $(n=2)$ constrained our choice of statistical analysis to simple analyses such as one-way ANOVA, $t$ test, or regression analysis for samples collected on the same day, and no statistical significance could be reported for ${ }^{15} \mathrm{~N}$ level across different points in time. Nonetheless, the synthesis of the information across time and space does provide insights into $\mathrm{N}$ dynamics within a $\mathrm{N}$-limited watershed.

\section{Results}

\section{Short-term dynamics}

${ }^{15} \mathrm{~N}$ recovery in the soil and the green layer.-More than $99 \%$ of the added ${ }^{15} \mathrm{~N}$ was recovered in the soil and the green layers immediately (1 day) after addition, and recovery remained high through the first growing season (Fig. 2). The green layer retained $>63 \%$ of all recovered ${ }^{15} \mathrm{~N}$ in the ground at both 1 day and 1 month. The first organic layer was the second largest sink for ${ }^{15} \mathrm{~N}$ at these dates, and this and the green layers together retained $>86 \%$ of ${ }^{15} \mathrm{~N}$ added.

Chloroform-fumigation and salt-extractable $N$ vs. residual $N$. - Only 1.5 months after addition, most (89$97 \%$ ) of the ${ }^{15} \mathrm{~N}$ in the first organic layer was in the nonextractable pool $\left(\mathrm{N}_{\mathrm{res}}\right)$ at all sites, whereas $\leq 3 \%$ of recovered ${ }^{15} \mathrm{~N}$ in this soil layer was found in salt $\left(\mathrm{K}_{2} \mathrm{SO}_{4}\right)$-extractable dissolved $\mathrm{N}(\mathrm{SEDN})$ and $\leq 9 \%$ in chloroform-fumigation-extractable N (CFN; Table 2). The SEDN and CFN pools together accounted for $<4 \%$ of total added ${ }^{15} \mathrm{~N}$ in all sites.

$N$ in soil pore water and WEDN.-During the growing season, dissolved organic $\mathrm{N}$ (DON) was the dominant form of $N(\geq 90 \%$ of total dissolved $N$ [TDN]) in both lysimeter water and water-extractable dissolved $\mathrm{N}$ (WEDN; Table 3). The ${ }^{15} \mathrm{~N}$ atom percent excess of pore water at 10 and $20 \mathrm{~cm}$ (approximately at the bottom of first and second organic layers, respectively) showed a sharp drop (a factor of nine, on average) within the first month (Fig. 3).

${ }^{15} \mathrm{~N}$ atom percent excess of the WEDN pool was $2-7$ times greater in the first organic layer than in the second organic layer (Fig. 4), as observed for the bulk soil (Fig. 2). Measured ${ }^{15} \mathrm{~N}$ atom percent excess of the WEDN pool within the first organic layer was significantly greater at Crest than all other sites immediately after the addition (6 days), corresponding with the highest ${ }^{15} \mathrm{~N}$ recovery for this soil layer at Crest (Fig. 2). Contrary to the decreasing trend within the first month of ${ }^{15} \mathrm{~N}$ addition observed for the pore water collected by lysimeters at $10 \mathrm{~cm}$, mean ${ }^{15} \mathrm{~N}$ atom percent excess of the WEDN pool in the first organic layer increased by up to fivefold on average during the same time period for all but Crest sites. The highest increase in atom percent excess of WEDN was observed at NWT and Riparian sites.

\section{Long-term dynamics}

${ }^{15} \mathrm{~N}$ recovery in the soil and green layer.-The strong ${ }^{15} \mathrm{~N}$ retention in the ground layers during the first growing season persisted even after two years, with

TABLE 3. Concentrations of dissolved $\mathrm{N}$ in soil pore water and water-extractable dissolved N (WEDN).

\begin{tabular}{lcrc}
\hline \hline Layer, depth & $\mathrm{N}$ form & $\begin{array}{r}\text { Lysimeter } \\
(\mu \mathrm{mol} / \mathrm{L})\end{array}$ & $\begin{array}{c}\text { WEDN } \\
(\mu \mathrm{mol} / \mathrm{g} \text { soil })\end{array}$ \\
\hline First organic, $10 \mathrm{~cm}$ & $\mathrm{NO}_{3}$ & $0.3(0.03)$ & $0.04(0.01)$ \\
& $\mathrm{NH}_{4}$ & $1.6(0.20)$ & $0.09(0.01)$ \\
& $\mathrm{DON}$ & $25.6(2.11)$ & $2.37(0.18)$ \\
Second organic, 20 cm & $\mathrm{NO}_{3}$ & $0.7(0.12)$ & $0.05(0.01)$ \\
& $\mathrm{NH}_{4}$ & $2.0(0.26)$ & $0.05(0.01)$ \\
& $\mathrm{DON}$ & $24.1(1.32)$ & $1.67(0.17)$ \\
\hline
\end{tabular}

Notes: Data shown are means (SE) across all locations during the growing season. DON is dissolved organic N. 


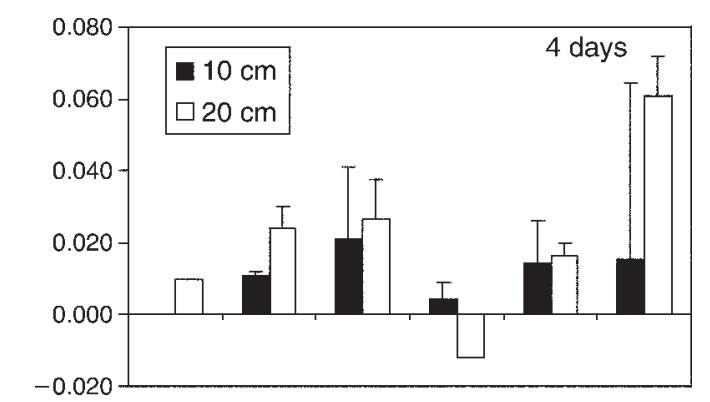

(Footslope_NWT) and Riparian sites and was due to very high ${ }^{15} \mathrm{~N}$ recovery in one sample of the first organic layer (two to three times greater than the mean of all sites, Fig. 2).

Throughout the first 2 years, the green layer was the largest sink for added ${ }^{15} \mathrm{~N}$; at both year 1 and 2 this layer still retained $\sim 60 \%$ or more of added ${ }^{15} \mathrm{~N}$. Combined with the second largest ${ }^{15} \mathrm{~N}$ sink (first organic layer), the upper two ground layers retained $66 \%$ of added ${ }^{15} \mathrm{~N}$ at
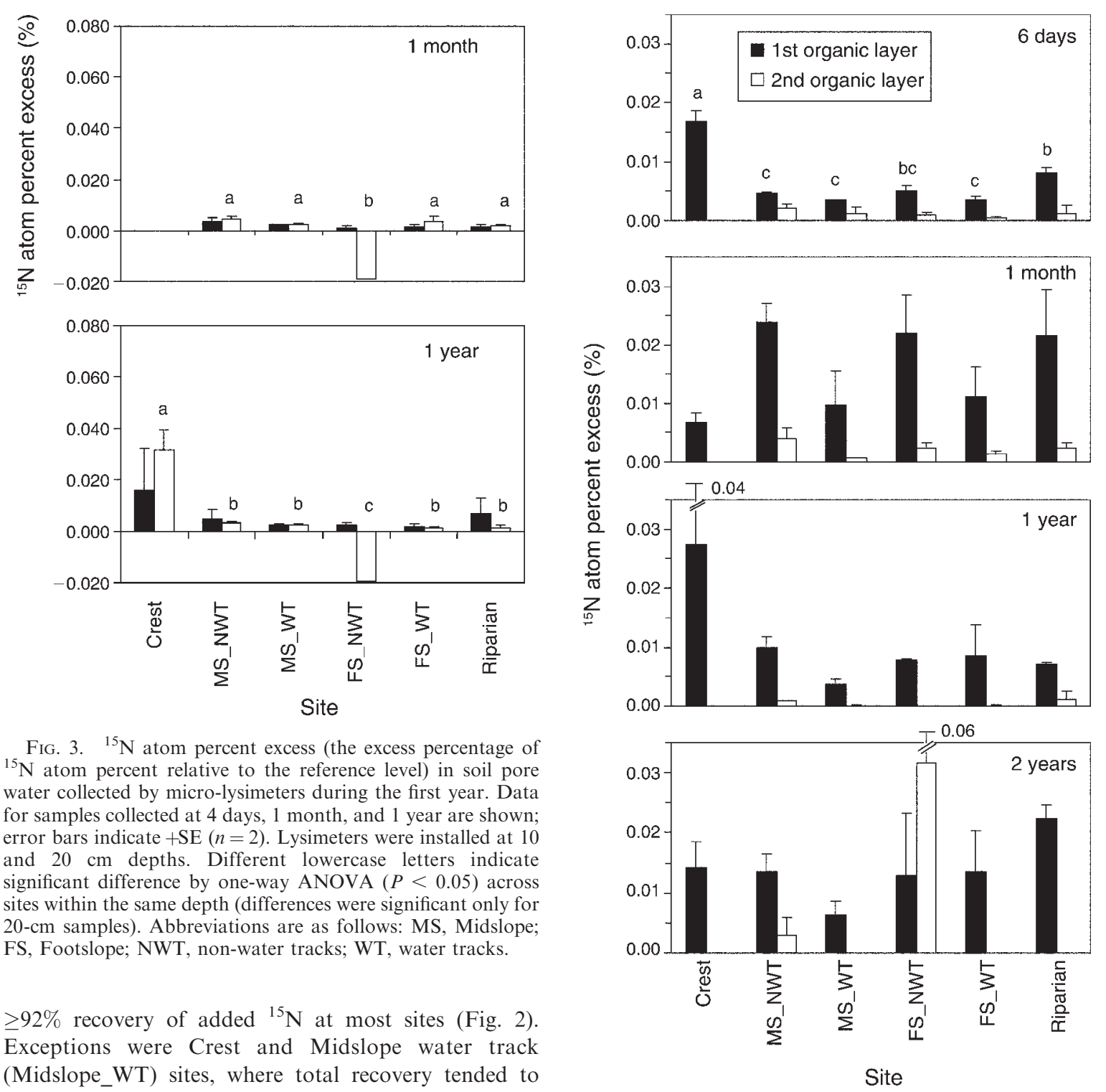

FIG. 3. ${ }^{15} \mathrm{~N}$ atom percent excess (the excess percentage of ${ }^{15} \mathrm{~N}$ atom percent relative to the reference level) in soil pore water collected by micro-lysimeters during the first year. Data for samples collected at 4 days, 1 month, and 1 year are shown; error bars indicate $+\mathrm{SE}(n=2)$. Lysimeters were installed at 10 and $20 \mathrm{~cm}$ depths. Different lowercase letters indicate significant difference by one-way ANOVA $(P<0.05)$ across sites within the same depth (differences were significant only for 20 -cm samples). Abbreviations are as follows: MS, Midslope; FS, Footslope; NWT, non-water tracks; WT, water tracks.

$\geq 92 \%$ recovery of added ${ }^{15} \mathrm{~N}$ at most sites (Fig. 2). Exceptions were Crest and Midslope water track (Midslope_WT) sites, where total recovery tended to decrease over time with $89 \%$ (Crest) and 69\% (Midslope_WT) of the added ${ }^{15} \mathrm{~N}$ recovered at the end of the second year. For Crest the decline was due mostly to decreased recovery in the soil (organic and mineral) layers, whereas for Midslope_WT recovery declined in both the green layer and soil layers. Extremely high total recovery (as high as $>180 \%$, much more than was added) was found only at Footslope non-water track

FIG. 4. ${ }^{15} \mathrm{~N}$ atom percent excess in water-extractable dissolved-N pool during the first two years. Data shown are soil extracts for 6 days, 1 month, 1 year, and 2 years; error bars indicate $+\operatorname{SE}(n=2)$. The first and second organic layers are those shown in Fig. 2. Note that all extraction was done at a soil: water ratio of $1: 10$, except for the second organic layer collected at 6 days and 1 month, for which a soil : water ratio of 1:5 was used. Abbreviations are as follows: MS, Midslope; FS, Footslope; NWT, non-water tracks; WT, water tracks. 
TABLE 4. Distribution of added ${ }^{15} \mathrm{~N}$ across hydrolysable-labile-N (HLN) and non-labile-N pools in the first organic layer.

\begin{tabular}{|c|c|c|c|c|c|c|c|c|c|}
\hline \multirow[b]{2}{*}{ Site } & \multicolumn{4}{|c|}{${ }^{15} \mathrm{~N}$ recovery of total added $(\%)$} & \multicolumn{5}{|c|}{$\begin{array}{c}\text { Contribution of } \mathrm{N} \text { pools to }{ }^{15} \mathrm{~N} \text { recovery } \\
\text { in first organic layer }(\%)\end{array}$} \\
\hline & $\mathrm{HNH}_{4}{ }^{+}$ & HAS & HAA & $\begin{array}{l}\text { Total } \\
\text { HLN }\end{array}$ & $\mathrm{HNH}_{4}{ }^{+}$ & HAS & HAA & $\begin{array}{l}\text { Total } \\
\text { HLN }\end{array}$ & $\begin{array}{c}\text { Non- } \\
\text { labile } \mathrm{N}\end{array}$ \\
\hline Crest & $0.3^{\mathrm{ab}}(0.0)$ & & $3.9^{\mathrm{ab}}(1.4)$ & $4.3^{\mathrm{ab}}(1.6)$ & $2.8(0.9)$ & & $35.2^{\mathrm{a}}(1.9)$ & $39.4(2.0)$ & 60.6 \\
\hline Midslope_NWT & $0.4^{\mathrm{ab}}(0.0)$ & $0.2(0.2)$ & $1.8^{\mathrm{ab}}(0.3)$ & $2.4^{\mathrm{ab}}(0.5)$ & $2.2(0.2)$ & $1.6(1.3)$ & $11.5^{\mathrm{b}}(4.4)$ & $15.3(5.9)$ & 84.7 \\
\hline Midslope WT & $0.2^{\mathrm{a}}(0.2)$ & $0.2(0.0)$ & $1.7^{\mathrm{a}}(0.8)$ & $2.1^{\mathrm{a}}(1.0)$ & $1.9(1.0)$ & $2.8(0.7)$ & $18.6^{\mathrm{ab}}(1.4)$ & $23.2(1.7)$ & 76.8 \\
\hline Footslope NWT & $1.0^{\mathrm{b}}(0.5)$ & $0.5(0.1)$ & $6.2^{\mathrm{ab}}(2.5)$ & $7.7^{\mathrm{ab}}(3.1)$ & $2.0(1.5)$ & $0.9(0.5)$ & $12.3^{\mathrm{ab}}(8.5)$ & $15.2(10.4)$ & 84.8 \\
\hline Footslope-WT & $0.3^{\mathrm{ab}}(0.0)$ & $0.4(0.1)$ & $3.4^{\mathrm{ab}}(0.8)$ & $4.2^{\mathrm{ab}}(0.9)$ & $2.2(0.2)$ & $2.5(0.6)$ & $22.3^{\mathrm{ab}}(4.9)$ & $27.0(5.6)$ & 73.0 \\
\hline Riparian & $0.9^{\mathrm{b}}(0.4)$ & $1.1(0.8)$ & $9.1^{\mathrm{b}}(5.2)$ & $11.2^{\mathrm{b}}(6.4)$ & $2.7(0.3)$ & $2.6(1.0)$ & $23.2^{\mathrm{ab}}(3.0)$ & $28.4(3.6)$ & 71.6 \\
\hline
\end{tabular}

Notes: The soils were collected at the end of the second year. Recovery of added ${ }^{15} \mathrm{~N}$ in hydrolyzable-labile- $\mathrm{N}$ (HLN) pools and the contribution of each pool to ${ }^{15} \mathrm{~N}$ recovered in the first organic layer are shown. HLN pools are $\mathrm{HNH}_{4}^{+}\left(\right.$hydrolyzable $\left.\mathrm{NH}_{4}^{+}\right)$, HAS (hydrolyzable amino sugars), and HAA (hydrolyzable amino acids). The effect of site on each N pool was determined by oneway ANOVA $(P<0.05)$ and is shown in superscripts when the differences are significant. Means $(\mathrm{SE})$ are shown $(n=2)$. The pool size $(\%)$ of non-LN was calculated as the difference between total ${ }^{15} \mathrm{~N}$ recovered in the first organic layer $(100 \%)$ and total HLN. NWT is non-water track; WT, water track.

Midslope_WT site, $84 \%$ at Crest, and $\geq 92 \%$ at all other sites at the end of second year. The mineral layer contributed little to ${ }^{15} \mathrm{~N}$ retention, except at the Crest, where the mineral soil (mean thickness above rocks $=4$ $\mathrm{cm}$ ) accounted for up to half of the overall recovery in the soil (Fig. 2).

Hydrolyzable- and non-hydrolyzable- $N$ pools.-Acid hydrolysis of the first organic layer after 2 years of ${ }^{15} \mathrm{~N}$ addition revealed that hydrolyzable-labile-N (HLN) pools (hydrolyzable $\mathrm{NH}_{4}^{+}$, amino sugar, and amino acids) were an important sink for ${ }^{15} \mathrm{~N}$ and were $15-39 \%$ of ${ }^{15} \mathrm{~N}$ retained in the first organic layer (Table 4). The non-labile-N pool, which is chemically less labile than HLN, contained the rest of the ${ }^{15} \mathrm{~N}$ (61-85\% of total $\left.{ }^{15} \mathrm{~N}\right)$. Within the HLN pool, hydrolyzable amino acid (HAA) was the dominant sink for added ${ }^{15} \mathrm{~N}$, containing on average four (non-Crest sites) to eight times (Crest) more ${ }^{15} \mathrm{~N}$ than hydrolyzable ammonium $\left(\mathrm{HNH}_{4}{ }^{+}\right)$and amino sugar (HAS) pools combined.

Of the ${ }^{15} \mathrm{~N}$ recovered in the first organic layer, the contribution of various $\mathrm{N}$ pools differed across sites. The HLN pool contributed most to ${ }^{15} \mathrm{~N}$ recovery at the Crest (39\%), whereas the non-labile-N pool was more important at the two NWT sites (85\%; Table 4). At the wetter sites (i.e., two WT sites and Riparian), the contribution of HLN was intermediate (23-28\%).

$N$ in soil pore water and WEDN.-The ${ }^{15} \mathrm{~N}$ atom percent excess of soil pore water collected at 10 and 20 $\mathrm{cm}$ by lysimeters after 1 year was low, similar to the amount at 1 month, except at the Crest site (Fig. 3). For the entire study period, ${ }^{15} \mathrm{~N}$ atom percent excess of the WEDN in the first organic layer generally was higher than the level observed immediately after (6 days) ${ }^{15} \mathrm{~N}$ addition (Fig. 4). In contrast, in the second organic layer, ${ }^{15} \mathrm{~N}$ atom percent excess of the WEDN disappeared entirely after the first year except in non-water track (NWT) sites. During the first 2 years, ${ }^{15} \mathrm{~N}$ recovered in the WEDN pool in the soil was only $<1 \%$ of added ${ }^{15} \mathrm{~N}$.

Recovery in the vegetation.-Combining the ${ }^{15} \mathrm{~N}$ results in this study with the biomass data from the same sites by Hahn et al. (1996) and Hastings et al. (1989), we found that ${ }^{15} \mathrm{~N}$ recovery by mosses was much greater than by vascular plants at all but the Riparian site, and this trend was magnified in year 2 for the tussock tundra sites (Midslope and Footslope; Table 5). At 1 year, mosses contained $20-50 \%$ of added ${ }^{15} \mathrm{~N}$ at all sites but the Riparian, whereas the entire aboveground biomass of the vascular plants contained only $6 \%$ at Riparian and 1-3\% at all other sites. Retention by the vascular plants declined over time and by year 2, vascular plants accounted for $\leq 1 \%$ of added ${ }^{15} \mathrm{~N}$ at all sites. In contrast, ${ }^{15} \mathrm{~N}$ recovery in the mosses increased from year 1 to year 2 at the tussock tundra sites (Midslope and Footslope), becoming the predominant ${ }^{15} \mathrm{~N}$ sink (Table 5, Fig. 2). If we make the unlikely assumption that $10 \%$ of the entire aboveground vascular biomass was found in the green layer, vascular plants could explain a maximum of $\sim 1 \%$ of the added ${ }^{15} \mathrm{~N}$.

For both 1- and 2-year samples, the partitioning of ${ }^{15} \mathrm{~N}$ between live mosses and non-moss components within the green layer differed across the sites (Fig. 2). The mosses were one of the major long-term sinks for added ${ }^{15} \mathrm{NH}_{4}{ }^{+}$especially at the tussock tundra sites (Midslope and Footslope). In contrast, the non-moss component, mostly plant detritus, was the dominant ${ }^{15} \mathrm{~N}$ sink at the Crest and Riparian tundra sites, accounting for $72-74 \%$ (Crest) and nearly $100 \%$ (Riparian) recovery within the green layer.

\section{Chemistry and movement of dissolved $N$ in downslope-flow waters}

DIN vs. DON.-Downslope-flow waters were dominated by DON across all seasons. Although $\mathrm{NO}_{3}{ }^{-}$was the dominant form $(66 \%)$ of TDN in the snowpack, unlike the soil waters collected during the growing season (Tables 3 and 6), this dominance quickly disappeared and $\mathrm{NO}^{3-}$ became $<1 \%$ of TDN as soon as the melt water from the snowpack made contact with the frozen ground and was collected as snowmelt water. The concentration of $\mathrm{NO}_{3}^{-}$stayed low for all water samples collected during the rest of the year. In contrast, 
TABle 5. Estimated ${ }^{15} \mathrm{~N}$ recovery in vascular plants and mosses.

\begin{tabular}{lcccc}
\hline \hline \multirow{2}{*}{$\begin{array}{c}\text { Time since } \\
{ }^{15} \mathrm{~N} \text { addition, site }\end{array}$} & \multicolumn{4}{c}{${ }^{15} \mathrm{~N}$ recovery in vegetation $\left(\%\right.$ of added $\left.{ }^{15} \mathrm{~N}\right)$} \\
\cline { 2 - 5 } & Evergreen shrub & Deciduous shrub & Graminoids & Mosses \\
\hline 1 yr & $2.1(0.50)$ & $1.2(0.02)$ & $0.0(0.00)$ & $18.5(11.62)$ \\
Crest & $0.9(0.06)$ & $0.2(0.02)$ & $0.3(0.05)$ & $50.8(2.90)$ \\
Midslope_NWT & $0.6(0.21)$ & $0.7(0.24)$ & $0.2(0.04)$ & $20.0(8.70)$ \\
Midslope_WT & $0.8(0.02)$ & $0.2(0.02)$ & $0.3(0.08)$ & $28.1(2.46)$ \\
Footslope_NWT & $0.6(0.16)$ & $0.6(0.18)$ & $0.2(0.05)$ & $32.0(1.67)$ \\
Footslope_WT & & & $5.7(3.18)$ & $0.9(0.26)$ \\
Riparian & & & & \\
2 yr & $0.9(0.00)$ & $0.5(0.07)$ & $0.0(0.00)$ & $20.3(8.42)$ \\
Crest & $0.6(0.03)$ & $0.1(0.02)$ & $0.1(0.01)$ & $86.9(5.60)$ \\
Midslope_NWT & $0.4(0.08)$ & $0.3(0.07)$ & $0.1(0.00)$ & $54.8(11.69)$ \\
Midslope_WT & $0.5(0.06)$ & $0.2(0.02)$ & $0.1(0.01)$ & $83.9(4.17)$ \\
Footslope_NWT & $0.4(0.07)$ & $0.5(0.02)$ & $0.1(0.02)$ & $58.3(15.83)$ \\
Footslope_WT & & & $0.7(1.23)$ & $1.1(0.12)$ \\
Riparian & & & & \\
\hline
\end{tabular}

Notes: The total recovery of ${ }^{15} \mathrm{~N}$ in vegetation was determined using the $\delta^{15} \mathrm{~N}$ values of vegetation measured within the enriched plots and the biomass estimates by Hahn et al. (1996) and Hastings et al. (1989). NWT is non-water track; WT, water track. Blank cells indicate that there were no deciduous or evergreen shrubs at this location.

DON, which was a minor component of TDN in the snowpack (17\%), increased rapidly as the melt event progressed, comprising $90-96 \%$ of TDN in downslopeflow water during snowmelt and 96-99\% during soilmelt. DON remained a predominant fraction throughout the growing season (95-96\% of TDN; Table 6).

Mobility and transport of ${ }^{15} \mathrm{~N}-T D N$. - The ${ }^{15} \mathrm{~N}$ enrichment in downslope-flow water within the ${ }^{15} \mathrm{~N}$-treated plots was measured as ${ }^{15} \mathrm{~N}$ atom percent excess of TDN. For the snowmelt period, the enrichment differed by site for both 2004 and 2006, and was roughly two- to threefold greater at Crest than at other sites (Fig. 5), whereas the enrichment was more similar among sites during the soilmelt.
Through the 2004 season, ${ }^{15} \mathrm{~N}$ atom percent excess of downslope-flow waters within the plots was generally larger during snowmelt than during soilmelt or the growing season (Fig. 6). Even though ${ }^{15} \mathrm{~N}$ atom percent excess of downslope-flow water declined with increasing distance from the plots, at Midslope sites the atom percent excess below the treatment plots was still elevated $(P<0.05)$ relative to the reference location above the plots at all sampling dates. In contrast, the atom percent excess of water below the treatment plots was not elevated significantly relative to the reference location at Footslope and Riparian sites $(P>0.05)$.

At least some dissolved ${ }^{15} \mathrm{~N}$ leached downslope in all seasons at Midslope sites. The negative linear relationship

TABLE 6. Concentrations of dissolved $\mathrm{N}$ in snow and downslope-flow waters.

\begin{tabular}{ccccc}
\hline \hline $\begin{array}{c}\text { Year, } \\
\mathrm{N} \mathrm{form}\end{array}$ & $\begin{array}{c}\text { N dissolved } \\
\text { in snowpack } \\
(\mu \mathrm{mol} / \mathrm{L})\end{array}$ & $\begin{array}{c}\text { N dissolved } \\
\text { in snowmelt } \\
(\mu \mathrm{mol} / \mathrm{L})\end{array}$ & $\begin{array}{c}\text { N dissolved } \\
\text { in soilmelt } \\
(\mu \mathrm{mol} / \mathrm{L})\end{array}$ & $\begin{array}{c}\text { N dissolved in } \\
\text { growing season } \\
\text { waters }(\mu \mathrm{mol} / \mathrm{L})\end{array}$ \\
\hline 2003 & & & \\
$\mathrm{NO}_{3}$ & & & & $0.41(0.07)$ \\
$\mathrm{NH}_{4}$ & & & & $0.80(0.07)$ \\
$\mathrm{DON}$ & & & & $21.67(0.75)$ \\
2004 & $3.38^{\mathrm{a}}(0.22)$ & $0.12^{\mathrm{b}}(0.02)$ & $0.34^{\mathrm{c}}(0.05)$ & $0.25^{\mathrm{d}}(0.05)$ \\
$\mathrm{NO}_{3}$ & $0.91^{\mathrm{ab}}(0.06)$ & $1.28^{\mathrm{ab}}(0.17)$ & $1.64^{\mathrm{c}}(0.23)$ & $0.77^{\mathrm{d}}(0.12)$ \\
$\mathrm{NH}_{4}$ & $0.90^{\mathrm{a}}(0.14)$ & $28.21^{\mathrm{bc}}(1.06)$ & $44.92^{\mathrm{d}}(1.69)$ & $27.06^{\mathrm{bc}}(0.88)$ \\
$\mathrm{DON}$ & & & & \\
2006 & 3.86 & $0.26^{\mathrm{a}}(0.04)$ & $0.05^{\mathrm{b}}(0.03)$ & \\
$\mathrm{NO}_{3}$ & 0.32 & $4.16^{\mathrm{a}}(0.30)$ & $0.70^{\mathrm{b}}(0.29)$ & \\
$\mathrm{NH}_{4}$ & & $43.16^{\mathrm{a}}(2.56)$ & $52.15^{\mathrm{b}}(2.49)$ & \\
$\mathrm{DON}$ & & & & \\
\hline
\end{tabular}

Notes: Data shown are means (SE) across all locations during spring melt within the first $2 \mathrm{yr}$. Only one snow sample (a composite sample of various topolocations) was taken in 2006. Letters in superscript show significant difference $(P<0.05)$ within the same $\mathrm{N}$ form across the melt stages. DON is dissolved organic N; blank cells indicate that the value is not determined. Snowmelt was collected on two (2004) and three (2006) separate dates, and soilmelt collected 9 days (2004) and 6 days (2006) after the last snowmelt collections. 


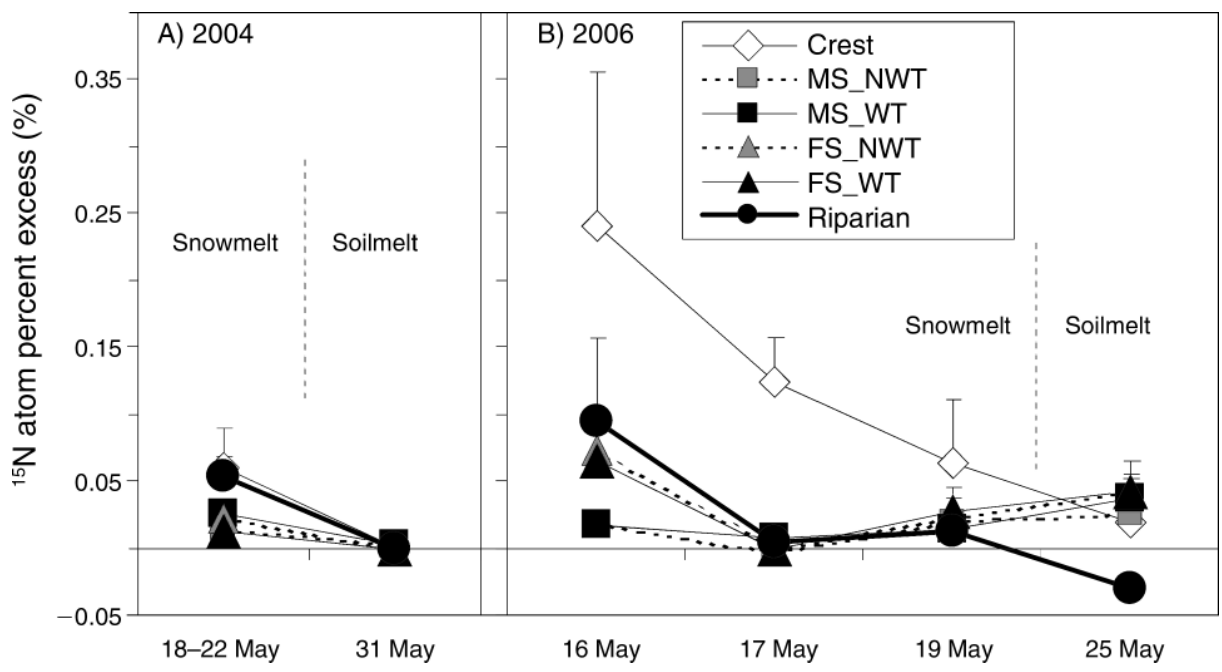

FIG. 5. Changes in relative release of ${ }^{15} \mathrm{~N}$ into dissolved $\mathrm{N}$ pool during snowmelt and soilmelt of 2004 and 2006; error bars show + SE. The relative release of ${ }^{15} \mathrm{~N}$ into the dissolved-N pool is shown as the magnitude of ${ }^{15} \mathrm{~N}$ atom percent excess. Downslopeflowing water was collected from within the ${ }^{15} \mathrm{~N}$-treated plots. Melting events are shown: (A) the melt event of 2004, where snowmelt collected on 18 and 22 May was composited prior to analysis for ${ }^{15} \mathrm{~N}$ enrichment; (B) the melt event of 2006, which had unusually thin snowpack due to an historically dry winter. Major slush-flow occurred on 18 May for both years. Abbreviations are as follows: MS, Midslope; FS, Footslope; NWT, non-water tracks; WT, water tracks.

between the natural $\log$ of ${ }^{15} \mathrm{~N}$ atom percent excess, $\ln (\mathrm{APE})$, and the distance from the plots for several sites indicates that enrichment of ${ }^{15} \mathrm{~N}$ in downslope-flow water declined exponentially as the water moved downhill (Fig. 7). At Midslope sites, the linear relationship held though the entire spring melt (snowmelt and soilmelt) of both 2004 and $2006\left(R^{2}=0.57-0.93\right)$, whereas at Crest, a tight linear relationship was found only during the snowmelt of normal snow year $\left(2004, R^{2}=0.95\right)$. For the Riparian site, the decline of ${ }^{15} \mathrm{~N}$ atom percent excess with distance was greatest; thus at this site only $1 \mathrm{~m}$ was required to reduce ${ }^{15} \mathrm{~N}$ in the water by the same proportion as at $5-10$ $\mathrm{m}$ below the other sites.

The loss of ${ }^{15} \mathrm{~N}$ atom percent excess in the downslopeflow water varied both temporally and spatially. Regardless of the initial enrichment, the distance required to reduce ${ }^{15} \mathrm{~N}$ atom percent excess by $95 \%$ $\left(D_{0.95}\right)$ at Midslope was greatest during the soilmelt

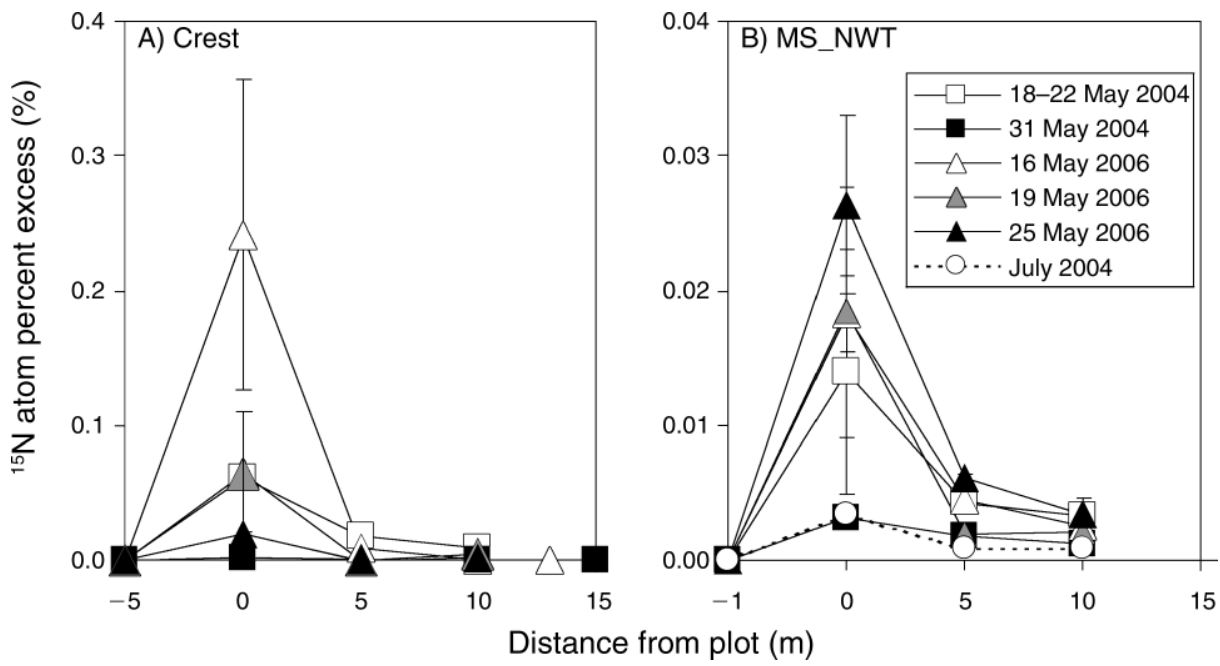

FIG. 6. Examples of changes in mean ${ }^{15} \mathrm{~N}$ atom percent excess across downslope-flow transects for snowmelt, soilmelt, and soil water during the growing season; error bars show \pm SE of measurement variability. Snowmelt and soilmelt were collected in 2004 , and 2006 and soil water was collected in summer 2004. Examples for (A) Crest and (B) Midslope_NWT are shown. Open and shaded symbols with solid lines indicate snowmelt; solid symbols with solid lines indicate soilmelt; and the dotted lines indicate downslope-flow water during the growing season. Other locations showed similar trends. For both panels, the $x$-axes indicate the distance from ${ }^{15} \mathrm{~N}$-treated plots; 0 is within a plot, $5-15 \mathrm{~m}$ are below the plots; negative numbers indicate reference locations $5 \mathrm{~m}$ (Crest) and $1 \mathrm{~m}$ (Midslope_NWT) uphill from the plots. Note that the scale of $y$-axes differs between the panels. 


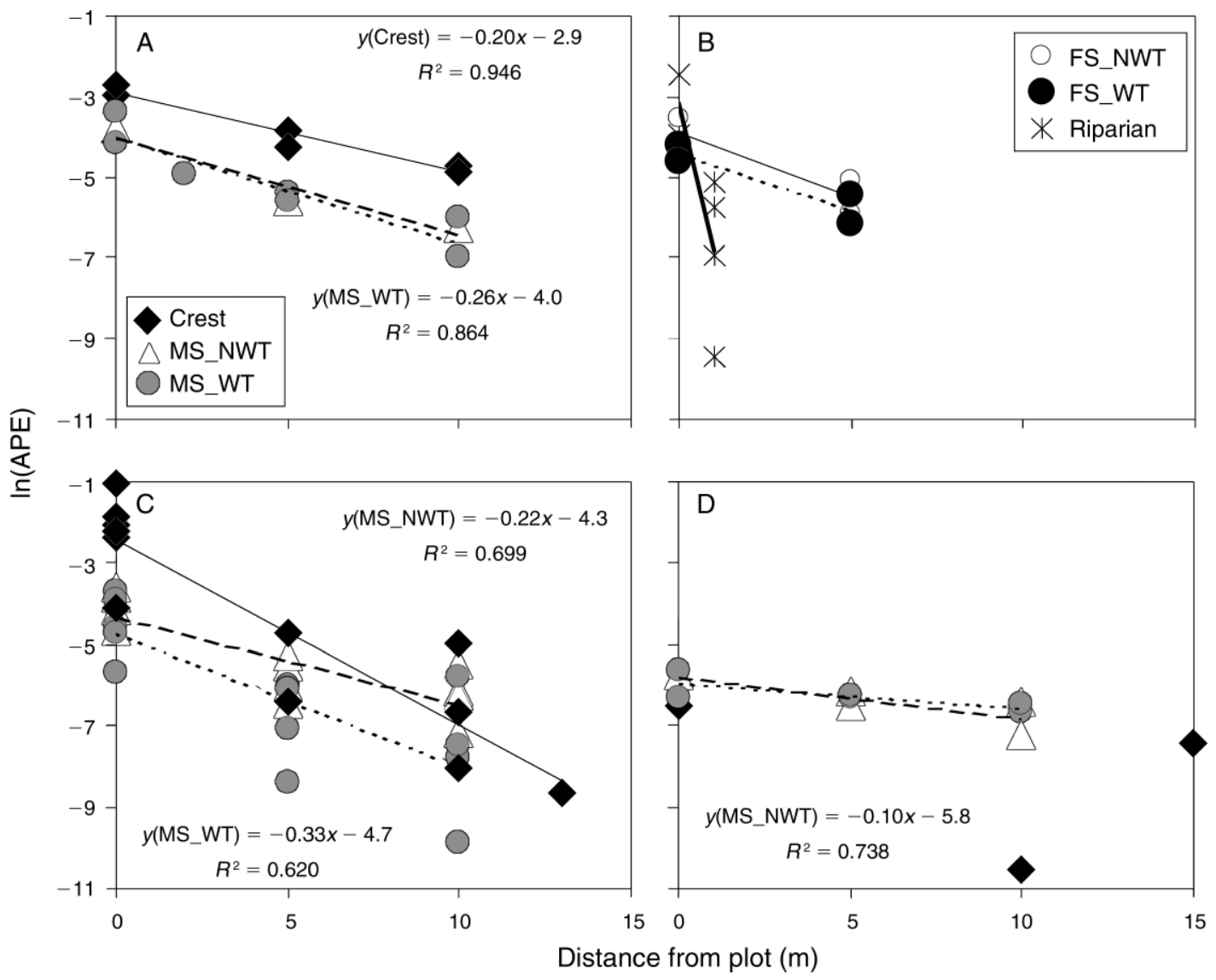

FIG. 7. Examples of relationships between the natural log of atom percent excess $\ln (\mathrm{APE})$ and distance from the ${ }^{15} \mathrm{~N}$-treated plots during the melt season. Snowmelt of 2004 is shown for (A) Crest and Midslope and (B) Footslope and Riparian locations; (C) 2006 snowmelt is shown for Crest and Midslope; and (D) 2004 soilmelt for Crest and Midslope. For 2004 snowmelt, 18 and 22 May samples were pooled prior to ${ }^{15} \mathrm{~N}$ analysis; for 2006 snowmelt, 16, 17, and 19 May samples were analyzed separately and plotted together. Regression line equations are shown for those with a slope that is significantly different from $0(P<0.05)$.

TABLE 7. Estimated distance from the plots that is required for $50 \%\left(D_{0.5}\right)$ and $95 \%\left(D_{0.95}\right)$ reduction in ${ }^{15} \mathrm{~N}$-atom percent excess.

\begin{tabular}{|c|c|c|c|c|c|c|c|c|c|c|}
\hline \multirow[b]{4}{*}{ Site } & \multicolumn{10}{|c|}{ Distance (m) } \\
\hline & \multicolumn{4}{|c|}{ Snowmelt } & \multicolumn{4}{|c|}{ Soilmelt } & \multirow{2}{*}{\multicolumn{2}{|c|}{$\begin{array}{c}\text { Summer } \\
2004\end{array}$}} \\
\hline & \multicolumn{2}{|c|}{2004} & \multicolumn{2}{|c|}{2006} & \multicolumn{2}{|c|}{2004} & \multicolumn{2}{|c|}{2006} & & \\
\hline & $D_{0.5}$ & $D_{0.95}$ & $D_{0.5}$ & $D_{0.95}$ & $D_{0.5}$ & $D_{0.95}$ & $D_{0.5}$ & $D_{0.95}$ & $D_{0.5}$ & $D_{0.95}$ \\
\hline Crest & 3.5 & 15.2 & 1.3 & 5.5 & NA & NA & NA & NA & ND & ND \\
\hline Midslope_NWT & 2.8 & 12.2 & 3.2 & 13.7 & 6.6 & 28.6 & 3.5 & 15.0 & 5.3 & 23.1 \\
\hline Midslope_WT & 2.7 & 11.5 & 2.1 & 9.1 & 11.8 & 50.8 & 2.6 & 11.1 & 3.3 & 14.2 \\
\hline Footslope_NWT & 2.1 & 9.3 & 2.3 & 9.9 & ND & ND & 2.0 & 8.8 & ND & ND \\
\hline Footslope_WT & 2.5 & 10.8 & 1.9 & 8.4 & ND & ND & 1.1 & 4.9 & ND & ND \\
\hline Riparian & 0.2 & 0.8 & 0.7 & 3.0 & ND & ND & NA & NA & ND & ND \\
\hline
\end{tabular}

Notes: The table reports the distance at which $50 \%\left(D_{0.5}\right)$ and $95 \%\left(D_{0.95}\right)$ reduction of ${ }^{15} \mathrm{~N}$-atom percent excess (APE) was estimated for snowmelt and soilmelt $(2004,2006)$ and downslope-flow water during the growing season (2004). The equations for regression lines between natural log of APE, $\ln (\mathrm{APE})$, and distance were used for the estimation (example equations shown in Fig. 7). Note that soilmelt at the crest site did not show a liner relationship between $\ln (\mathrm{APE})$ and distance and that the riparian site did not show detectable APE for soilmelt of 2006. During the growing season, the soil at the crest was too dry to generate downslopeflow water. All values indicate distance $(\mathrm{m})$ from the ${ }^{15} \mathrm{~N}$-addition plots. NWT indicates non-water track; WT, water track; ND, not determined due either to sampling not being attempted or that sampling was attempted but it was impossible to collect samples; NA, not applicable due to no linear relationship between $\ln ($ APE) and distance (Crest) or to no detectable APE (Riparian).

Mean snowpack-water equivalent for the years 1985-1990, calculated from data reported by Hinzman et al. (1996), was used to calculate the volume of runoff water (i.e., downslope-flow water). We assumed that, during the snowmelt, each site received all water in the snowpack directly above it because the frozen ground would prevent penetration of water and because little, if any, evapotranspiration would be occurring during this time. 


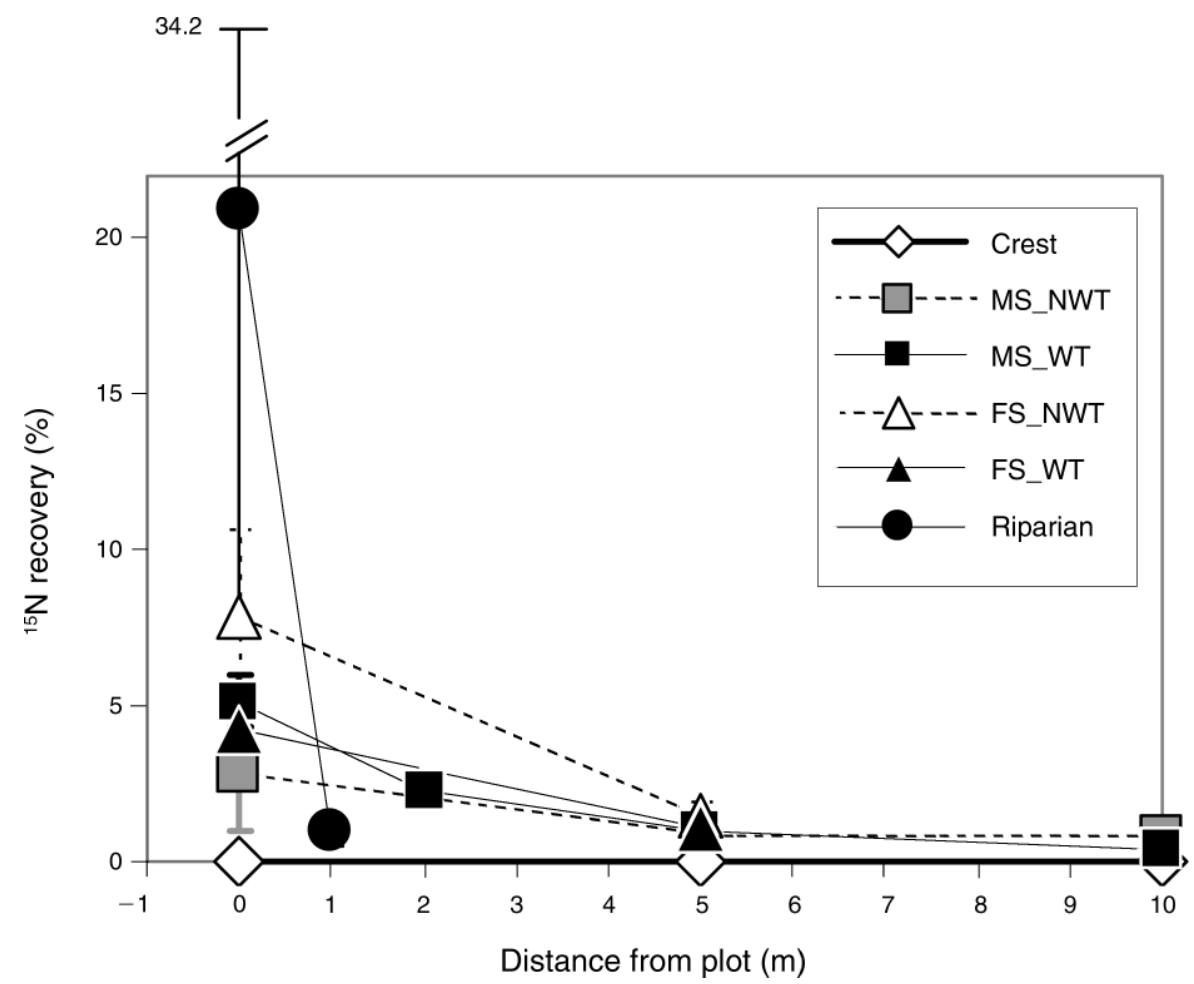

FIG. 8. Estimation of ${ }^{15} \mathrm{~N}$ recovery in the total dissolved nitrogen (TDN) pool of downslope-flow water for each site during the 2004 snowmelt period. The snowmelt water (downslope-flow water) was collected in 2004 from the downslope transect (Fig. 1B) and its ${ }^{15} \mathrm{~N}$ atom percent excess for TDN pool was determined. The atom percent excess values were then multiplied by the estimated volume of snowmelt water running down the hillslope (Table 1). Upon calculation of atom percent excess, snowmelt water collected from above the ${ }^{15} \mathrm{~N}$-addition plot served as a reference. A distance of $0 \mathrm{~m}$ indicates collection within the ${ }^{15} \mathrm{~N}$ treated plots; positive values of distance indicate that the sampling location is downhill from the plot. Note that the recovery shown here only accounts for ${ }^{15} \mathrm{~N}$ dissolved in water and thus does not include ${ }^{15} \mathrm{~N}$ that is retained in the solid phase.

compared to other seasons (Table 7). During the soilmelt of 2004 , the $D_{0.95}$ at Midslope was $29-51 \mathrm{~m}$, $\sim 2-4$ times greater than during the snowmelt and up to four times farther than during the growing season (Table 7). Although smaller in magnitude, the $D_{0.95}$ at Midslope for the soilmelt of 2006 was also greater than for snowmelt (1.1-1.2 times). The $D_{0.95}$ at more steeply sloping sites (Crest and Midslope) was on average twice as great as on less steep sites (Footslope and Riparian), with Riparian sites having the shortest $D_{0.95}: 1 \mathrm{~m}$ (2004) and $3 \mathrm{~m}$ (2006).

We estimated the total amount of ${ }^{15} \mathrm{~N}$ mobilized from soil during the snowmelt of 2004, a year of near-normal snowpack, using ${ }^{15} \mathrm{~N}$ atom percent excess of TDN and the estimated volume of downslope-flow water during snowmelt (Table 1). When the volume of the downslopeflow water was taken into account, the largest total ${ }^{15} \mathrm{~N}$ release from the plots into the water occurred at the Riparian site (21\% of initial ${ }^{15} \mathrm{~N}$ added), which had roughly 600 times more surface-water flow (based on upslope drainage area) than the Crest (Fig. 8). In contrast, although the ${ }^{15} \mathrm{~N}$ enrichment at the Crest was the highest of all sites (Fig. 5), the total ${ }^{15} \mathrm{~N}$ release during the snowmelt accounted for the smallest proportion of ${ }^{15} \mathrm{~N}$ among all sites $\left(0.04 \%\right.$ of the added ${ }^{15} \mathrm{~N}$; Fig.
8). As observed for ${ }^{15} \mathrm{~N}$ atom percent excess, nearly all $(96 \%)$ of the ${ }^{15} \mathrm{~N}$ released into the snowmelt water at the Riparian site disappeared within $1 \mathrm{~m}$ of the plots.

\section{DisCUSSION}

At Imnavait Creek, Alaska, USA, ${ }^{15} \mathrm{NH}_{4}{ }^{+}-\mathrm{N}$ deposited on the tundra surface followed two alternative pathways during the first growing season: it either remained relatively labile in the green layer $\left(>70 \%\right.$ of added $\left.{ }^{15} \mathrm{~N}\right)$, or it became stabilized into a recalcitrant-soil-N pool below the green layer $(<30 \%)$, presumably via turnover of microbial biomass (Fig. 9). The strong $\mathrm{N}$ sink within the green layer suggests that this thin surface layer plays a key role in $\mathrm{N}$ cycling in this tundra ecosystem.

Added ${ }^{15} \mathrm{~N}$ was tightly retained, with very little loss over 3 years from all but Crest and Midslope_WT sites, where ${ }^{15} \mathrm{~N}$ was likely lost in vertical or horizontal leaching (Fig. 9). The strong and persistent retention of ${ }^{15} \mathrm{~N}$ within the green layer and relatively recalcitrantsoil- $\mathrm{N}$ pool contributes significantly to the chronic $\mathrm{N}$ limitation in this ecosystem.

A conceptual model of the downhill movement of ${ }^{15} \mathrm{~N}$ along the Imnavait Creek hillslope (Fig. 10) suggests that hydrology played the single most important role in mobilizing the retained ${ }^{15} \mathrm{~N}$, resulting in a greater ${ }^{15} \mathrm{~N}$ 


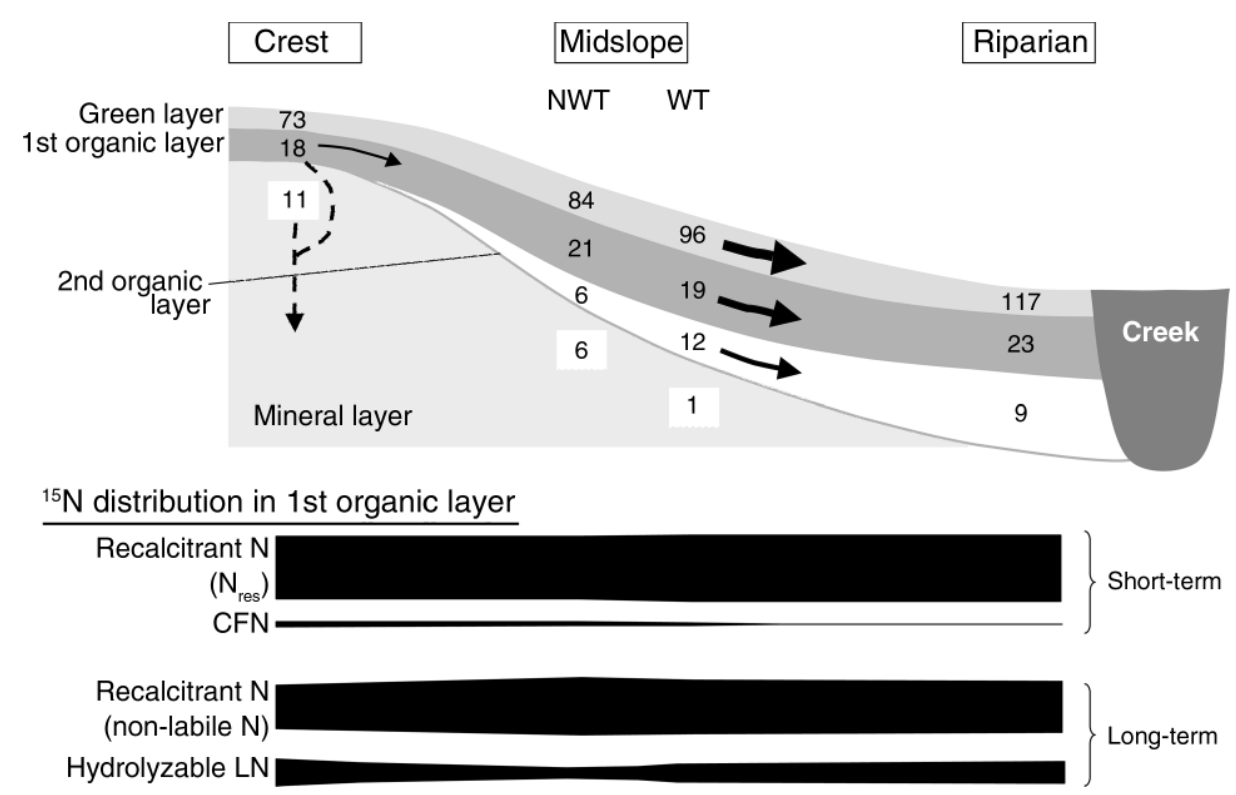

FIG. 9. Conceptual models of initial ${ }^{15} \mathrm{~N}$ retention and subsequent movement along the hillslope of Imnavait Creek watershed along with short- and long-term ${ }^{15} \mathrm{~N}$ distribution in soil. The values indicate average short-term recovery of ${ }^{15} \mathrm{~N}$ (percentage of added) within each green or soil layer. Footslope sites were omitted for simplicity. The solid arrows indicate subsequent movement of ${ }^{15} \mathrm{~N}$ via water flowing downslope, and the dashed arrows show possible pathways of ${ }^{15} \mathrm{~N}$ leaching. The width of arrows indicates relative magnitude of ${ }^{15} \mathrm{~N}$ movement. The bars at the bottom show short- and long-term ${ }^{15} \mathrm{~N}$ distribution within the first organic layer among various $\mathrm{N}$ pools across the sites along the hillslope. The width of the bars indicates the contribution of each pool to ${ }^{15} \mathrm{~N}$ retention relative to other pools. $\mathrm{N}_{\text {res }}$ is residual $\mathrm{N}$ after chloroform-fumigation extraction; CFN is chloroform-fumigation extractable $\mathrm{N}$; hydrolyzable $\mathrm{LN}$ is total hydrolyzable labile $\mathrm{N}$ (hydrolyzable $\mathrm{NH}_{4}{ }^{+}$, amino acids, and amino sugars); non-labile $\mathrm{N}$ is total ${ }^{15} \mathrm{~N}$ recovered in the first organic layer $(100 \%)$ - total hydrolyzable LN.

release into downslope-flow water at water track (WT) and Riparian sites than at non-water track (NWT), and during snowmelt than other times of the year. Losses of ${ }^{15} \mathrm{~N}$ were driven by a combination of total ${ }^{15} \mathrm{~N}$ released in gravitational-flow water, the $\mathrm{N}$-immobilization capacity of the system, and the flow rate of the water. Thus we hypothesize that ${ }^{15} \mathrm{~N}$ retained in the ground is most vulnerable to losses at Midslope_WT during soilmelt, mainly because of asynchrony between the timing of the release and biological and nonbiological immobilization. In contrast, $\mathrm{N}$ losses at Crest occur mainly by vertical leaching to deep mineral soil. Together, these leaching losses further intensify $\mathrm{N}$ limitation in this ecosystem.

\section{Short-term dynamics}

Over $70 \%$ of all the added ${ }^{15} \mathrm{NH}_{4}{ }^{+}-\mathrm{N}$ was immediately and tightly retained within the green layer across all sites (Fig. 9). The high mean recovery during the first growing season at Midslope and Footslope sites (73$117 \%$ ) was largely due to the mosses' ability to retain incoming ${ }^{15} \mathrm{NH}_{4}{ }^{+}$at high efficiency, and because mosses dominated total biomass at these sites $(58-79 \%$ of total biomass; Hahn et al. 1996). In contrast the non-moss component, mainly plant detritus rather than live vascular plants, was the major sink for ${ }^{15} \mathrm{~N}$ at Crest and Riparian sites, where moss accounted for only 1$17 \%$ of total biomass (Hahn et al. 1996). Uptake by vascular plants within the green layer was unimportant at all sites, because even with our highest estimate of ${ }^{15} \mathrm{~N}$ recovery by vascular plants in the green layer, we could explain only $\sim 1 \%$ of ${ }^{15} \mathrm{~N}$ recovery.

Fast and strong retention of $\mathrm{NH}_{4}^{+}$has been reported for both mosses and plant detritus. Many moss species can take up water and nutrients over their entire surface (Turetsky 2003), and thus efficiently scavenge both $\mathrm{NH}_{4}{ }^{+}$ and $\mathrm{NO}_{3}{ }^{-}$at low concentrations (Press and Lee 1982, Turetsky 2003). Additionally, some Sphagnum species possess cation exchange capacity on their cell walls (Clymo 1963), capturing atmospherically deposited $\mathrm{NH}_{4}{ }^{+}$ along with other cations. By monitoring ${ }^{15} \mathrm{NH}_{4}{ }^{+}$added to the surface of Hylocomium species, Eckstein (2000) found that the mosses had high nutrient recycling ability and that most added ${ }^{15} \mathrm{~N}$ was allocated to new growth in the following year rather than being released to the soil. Our results are consistent with other studies: Kotanen (2002) found that mosses assimilated $\mathrm{N}$ more efficiently than higher plants, and Li and Vitt (1997) found that nearly all ${ }^{15} \mathrm{~N}$ added as atmospheric deposition was retained in the moss layer in boreal peatlands.

Decomposing plant detritus can be also a significant sink for added $\mathrm{NH}_{4}{ }^{+}$in northern temperate forests (Currie et al. 1999, Nadelhoffer et al. 1999) and in laboratory sorption experiments with peat, fulvic-, and humic-acids (Thorn and Mikita 1992). These studies point to nonbiological fixation (e.g., with quinones) as one of the major mechanisms that retains added $\mathrm{NH}_{4}{ }^{+}$. 


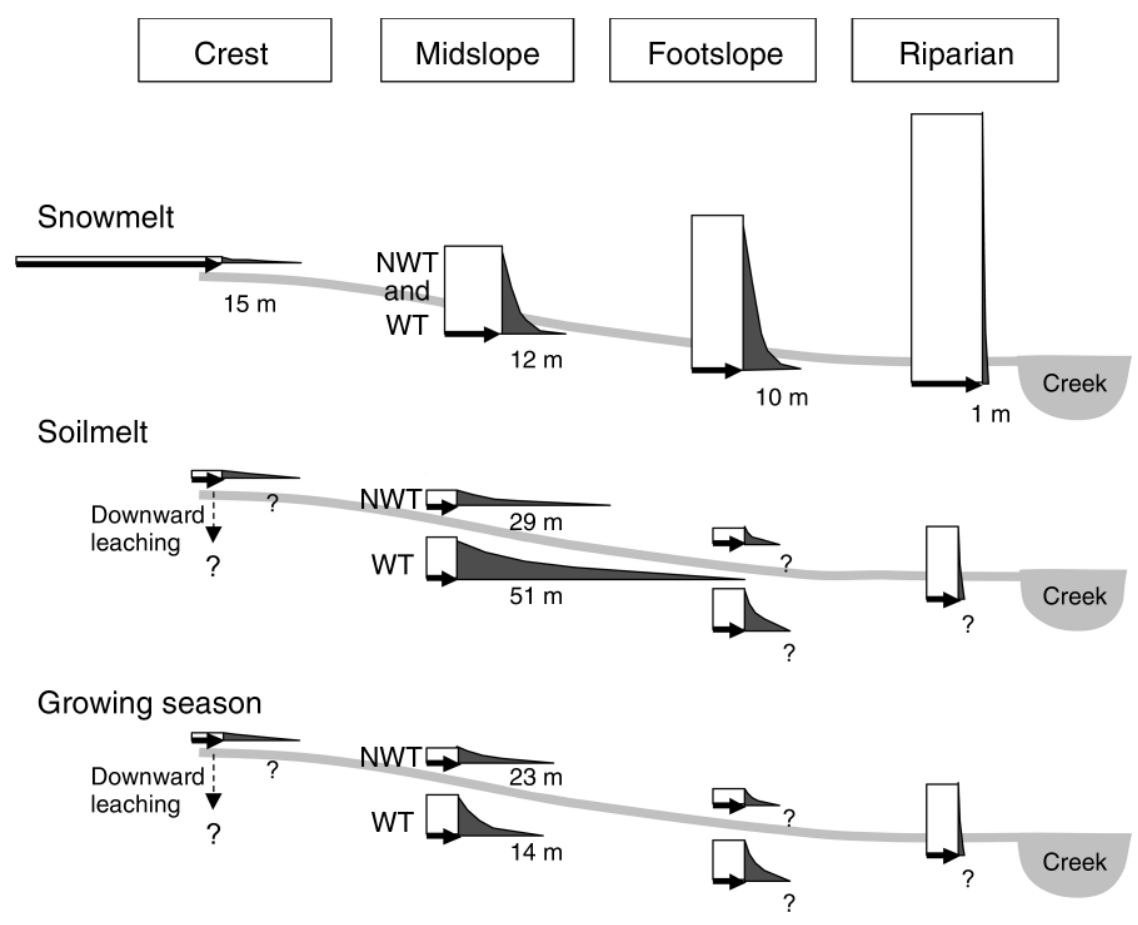

FIG. 10. Conceptual models of ${ }^{15} \mathrm{~N}$ movement along the hillslope of Imnavait Creek watershed. The movement of ${ }^{15} \mathrm{~N}$ is shown as the result of combined effects of relative release from the plots, flux of runoff water, and biological and nonbiological immobilization of the ${ }^{15} \mathrm{~N}$ in soil below the plots. The length of the solid arrows indicates relative ${ }^{15} \mathrm{~N}$ release $\left({ }^{15} \mathrm{~N}\right.$ atom percent excess of the downslope-flow water, based on 2004 data), the height of the open boxes indicates the magnitude of flux of runoff water, and the area of the boxes indicates total ${ }^{15} \mathrm{~N}$ released in downslope-flow water (as in Fig. 8). The width of the shaded graduated slope shows $D_{0.95}$ (the distance required to reduce ${ }^{15} \mathrm{~N}$ atom percent excess by $95 \%$; see Table 7 for the definition), which may be longer at steeper grades of the hill slope or smaller immobilization capacity of the soil. The shaded area indicates the amount of ${ }^{15} \mathrm{~N}$ transported downhill. Size and length of the arrows, boxes, and graduated slope show relative magnitude across the sites and seasons. Question marks indicate ${ }^{15} \mathrm{~N}$ release into downslope-flow water that was not determined in this study. The values are comparable to distances $(12 \mathrm{~m}, 10 \mathrm{~m}$, etc.) shown in Table 7.

Similarly, by tracing ${ }^{15} \mathrm{NH}_{4}^{+}$injected into tussock and soil cores near our study site, Schimel and Chapin (1996) found that the detritus was the dominant sink for ${ }^{15} \mathrm{~N}$ (2.7 times greater than live plants). They found that live graminoids (Carex) were the major sink for ${ }^{15} \mathrm{~N}$ in cores from a wet meadow near Imnavait Creek, recovering 21 times more ${ }^{15} \mathrm{~N}$ than plant detritus, but this may have been because ${ }^{15} \mathrm{~N}$ was injected into the rooting zone, where it would be immediately available for uptake, rather than applied to the surface where it would most likely be immobilized into litter and mosses.

Upon entering the first organic layer, ${ }^{15} \mathrm{~N}$ was quickly converted into recalcitrant forms of $\mathrm{N}$ within the first growing season $\left(\mathrm{N}_{\text {res }}>89 \%\right.$ of ${ }^{15} \mathrm{~N}$ recovered in the first organic layer). The small ${ }^{15} \mathrm{~N}$ recovery in the chloroform-fumigation-extractable-N (CFN) pool relative to $\mathrm{N}_{\text {res }}$ pool may be an indication of rapid turnover of microbial biomass (Table 2). Alternatively, nonbiological immobilization of ${ }^{15} \mathrm{~N}$ into recalcitrant soil organic matter, by such as $\mathrm{NH}_{4}{ }^{+}$fixation with quinones, may explain the greater recovery in $\mathrm{N}_{\text {res }}$. Transfer of undecomposed necromass of ${ }^{15} \mathrm{~N}$-enriched mosses to the first organic layer would not likely explain the high recovery of ${ }^{15} \mathrm{~N}$ in the $\mathrm{N}_{\text {res }}$ pool (Table 2), because the lifespan of Sphagnum and Hylocomium shoots is at least 2-3 years (Aerts et al. 1999, Eckstein 2000) and because if the necromass of mosses from the first growing season accounts for $22-31 \%$ of added ${ }^{15} \mathrm{~N}$ in the $\mathrm{N}_{\text {res }}$ pool at Midslope and Footslope sites (the $\mathrm{N}_{\text {res }}$ pool explained $89-97 \%$ of recovered ${ }^{15} \mathrm{~N}$ within the first organic layer; Table 2), we would see a large decline of ${ }^{15} \mathrm{~N}$ recovery in the green layer by the end of the third growing season.

Other short-term studies in tussock and wet-sedge tundras at nearby Toolik Lake have reported much higher recovery of ${ }^{15} \mathrm{~N}$ in the $\mathrm{CFN}$ pool than we found in this study $\left(<4 \%\right.$ of added $\left.{ }^{15} \mathrm{~N}\right)$. For example, Nordin et al. (2004) found that $20-28 \%$ of ${ }^{15} \mathrm{~N}$ injected to the tussock tundra $(0-10 \mathrm{~cm}$ below the moss layer) in July was recovered in the CFN pool after $4 \mathrm{~h}$, and Schimel and Chapin (1996), who also injected the label beneath the surface, found similar recovery for both tussock (39\%) and wet-meadow (22\%) tundras after 5 days of incubation in August. (Note: to estimate $\mathrm{CFN}$ in these previous studies, the reported microbial-N values were backcorrected for the extractability coefficient, $K_{\mathrm{n}}, 0.45$ for Nordin et al. [2004] and 0.54 for Schimel and Chapin [1996].) 
The much higher recovery in CFN in these previous studies can be attributed principally to the injection method, which bypasses the green layer that was the principal location of $\mathrm{NH}_{4}^{+}$retention in our study. The short duration between labeling and sampling (4 hours and 5 days) in the previous studies compared to ours (1.5 months) might also have resulted in greater recovery of ${ }^{15} \mathrm{~N}$ in microbial biomass. However, Schimel and Chapin (1996) found that $\mathrm{N}$ partitioning into different $\mathrm{N}$ pools within the first 5 days and 1 month was similar. A comparison of our study with these previous studies also suggests that the dominant sink for $\mathrm{NH}_{4}{ }^{+}$produced in the organic soil (e.g., by mineralization) is microbial biomass, whereas $\mathrm{NH}_{4}{ }^{+}$deposited on the surface is initially retained in the green layer.

The relatively high ${ }^{15} \mathrm{~N}$ atom percent excess values observed for the soil pore water 4 days after ${ }^{15} \mathrm{~N}$ addition indicate that a small fraction of ${ }^{15} \mathrm{~N}$ applied to the tundra surface penetrated quickly to as deep as $20 \mathrm{~cm}$, presumably facilitated by the rain event the night after ${ }^{15} \mathrm{~N}$ addition. The sharp declines in ${ }^{15} \mathrm{~N}$ atom percent excess between 4 days and 1 month were likely caused by turnover of the dissolved-N pool via uptake by microbes or plants, and by nonbiological stabilization of dissolved $\mathrm{N}$ followed by replenishment of the dissolved-N pool with natural-abundance-level $\mathrm{N}$. In this ecosystem, microbes and plants quickly take up nearly all $\mathrm{N}$ in labile forms. The dissolved-N pool would be subsequently replenished via slow dissimilation of soil organic $\mathrm{N}$ (Shaver et al. 1992), but dissolved $\mathrm{N}$ produced in this way would be less enriched with ${ }^{15} \mathrm{~N}$ because of discrimination against ${ }^{15} \mathrm{~N}$ during dissimilation and export (Dijkstra et al. 2008). This would lead to preferential stabilization of ${ }^{15} \mathrm{~N}$ into microbial biomass and the recalcitrant-soil-N pool. For example, for wide range of soil types, vegetation, and climate, Dijkstra et al. (2006) found that the microbial-N pool was $3.7 \%$ o larger than the extractable-N pool and that microbial ${ }^{15} \mathrm{~N}$ enrichment and net $\mathrm{N}$ mineralization rate were positively correlated. Similarly, in Swedish Lapland, Clemmensen et al. (2008) found that most ${ }^{15} \mathrm{~N}$ added as $\mathrm{NH}_{4}{ }^{+}, \mathrm{NO}_{3}{ }^{-}$, or glycine was retained in microbial biomass after 2 days, but half of the immobilized ${ }^{15} \mathrm{~N}$ was transferred to a non-extractable- $\mathrm{N}$ pool within 26 days and that ${ }^{15} \mathrm{~N}$ exported as dissolved $\mathrm{N}$ was $<1 \%$ during this time. In our study we found the opposite short-term ( $\leq 1$ month) trends in ${ }^{15} \mathrm{~N}$ atom percent excess, i.e., decreasing soil pore $\mathrm{N}$ and increasing WEDN over time (Figs. 3 and 4). This suggests that part of the ${ }^{15} \mathrm{~N}$ initially dissolved in soil pore water was removed over time and became more stable WEDN, perhaps via assimilation to microbial biomass or abiotic sorption.

\section{Long-term dynamics}

The loss of ${ }^{15} \mathrm{~N}$ over 2 years at Crest and Midslope_WT sites may be attributed to leaching (Fig. 9). At the Crest, the highly permeable mineral soil (rock content $=52 \%$ (mass $/$ mass), Appendix) and deep thaw beneath the thin $(\sim 4 \mathrm{~cm})$ organic mat facilitated a vertical leaching of ${ }^{15} \mathrm{~N}$ at significant rain events. Thaw depth in the heath tundra of the Crest in this study area exceeds $1 \mathrm{~m}$ (Everett et al. 1989). Thus, it is possible that ${ }^{15} \mathrm{~N}$ not recovered in our samples was retained in the mineral soil deeper than our sampling-depth limit $(8 \mathrm{~cm}$ because of obstruction by rocks). Gravitational downslope-flow water movement would also explain the decline of ${ }^{15} \mathrm{~N}$ recovery during our study period for Midslope_WT (Fig. 9). Although there was no difference in the depth of thaw or any clear gradient between NWT and WT (Y, Yano et al., unpublished data), we frequently observed a flow of water through and under the green layer in gaps between tussocks within the Midslope_WT, whereas no such flow was visible at Midslope_NWT. Thus, at Midslope_WT, greater flux of downslope-flow water within the Green and thawed organic layers during the snow-free season may have resulted in the loss of added ${ }^{15} \mathrm{~N}$ from the plots. At the Footslope_WT and Riparian, both horizontal and vertical movement of water is slower because of the smaller gradient of the slope and the shallower water table, leading to the small change over time in ${ }^{15} \mathrm{~N}$ recovery at Footslope and Riparian sites. Although some $\mathrm{N}$ could be lost via denitrification in the Riparian site, as suggested by the higher denitrification-enzyme activity in Riparian than Crest soils (Alexander-Ozinskas 2008), little overall losses of ${ }^{15} \mathrm{~N}$ at the Riparian site suggest that neither denitrification nor leaching losses are large there.

Nitrogen fixation could reduce the enrichment of ${ }^{15} \mathrm{~N}$ in the ground- $\mathrm{N}$ pool by dilution. However, this is not likely the reason for the decline of ${ }^{15} \mathrm{~N}$ at Crest and Midslope_WT sites, because the rate of $\mathrm{N}$ fixation near these sites $\left(\sim 0.08 \mathrm{~g} \cdot \mathrm{m}^{-2} \cdot \mathrm{yr}^{-1}\right.$; Hobara et al. 2006) was too low to account for the observed changes in the ${ }^{15} \mathrm{~N}$ atom percent of the ground- $\mathrm{N}$ pool (165-860 g/ $\mathrm{m}^{2}$ ). Furthermore, if dilution by $\mathrm{N}$ fixation were important, it should be observed at other sites, given the similar $\mathrm{N}$-fixation rate down the entire hillslope (Hobara et al. 2006).

The few measurements of extremely high ${ }^{15} \mathrm{~N}$ recovery at Footslope_NWT and Riparian (i.e., recovery of $>100 \%$ of the amount added; Fig. 2) were probably due to uneven distribution of ${ }^{15} \mathrm{~N}$ within the first organic layer as a result of the application method. This unevenness may have been amplified by disruption of the connectivity of soil water as the tundra progressively dried out in mid to late growing season. In 2003, the study area continued to dry through the early and mid-season until a rain event on 10 August (G. Shaver et al., unpublished data). The summer of 2005 was one of the driest years in the 30 year history of research at Imnavait Creek, and by the July sampling date, all surface water had disappeared, except for a few patches at Riparian. Because of the slight topographic gradient and lack of a water track 

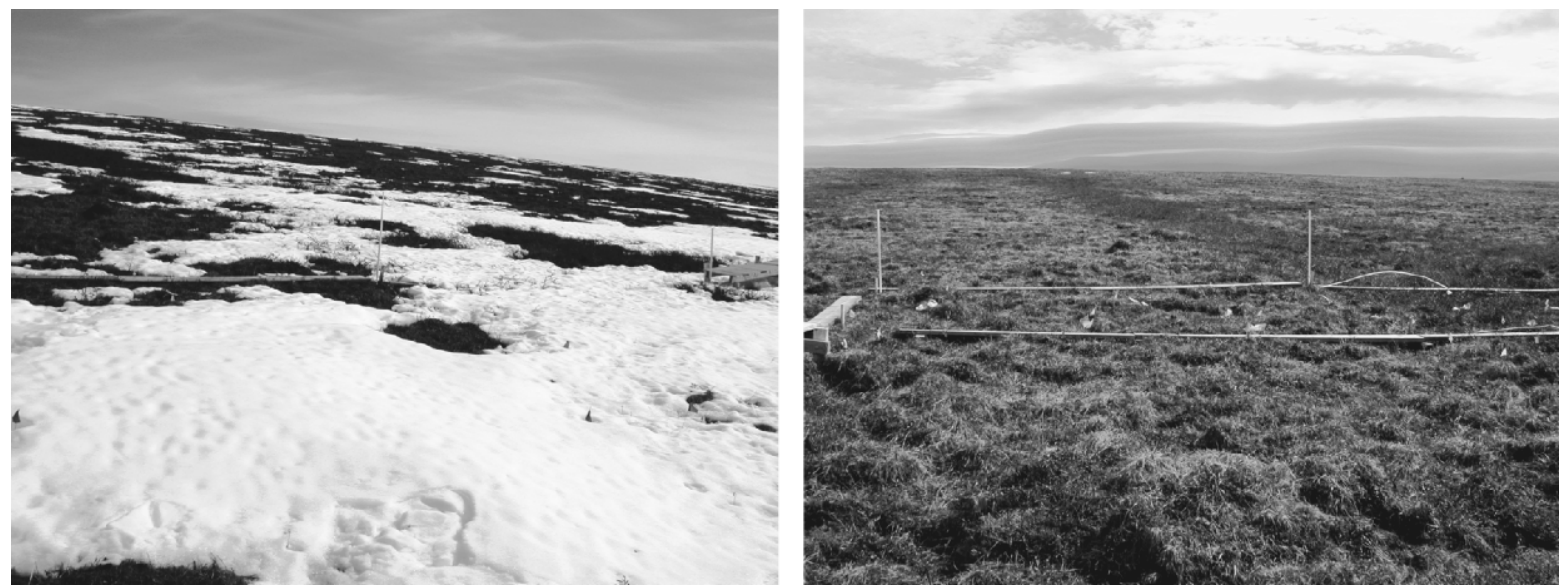

Plate 1. Transition from snowmelt to soilmelt at Midslope location in the Imnavait Creek watershed, north-central Alaska, USA. The left (snowmelt) photo was taken two days before the slush flow of the creek. In contrast, the right (soilmelt) photo was taken seven days after the slush flow, when the depth of the thaw extended only a few centimeters below the ground surface. The wooden platforms and poles mark the borders of the ${ }^{15} \mathrm{~N}$-addition plots. Photo credits: Y. Yano.

at Footslope NWT and Riparian sites, water in the soil would be expected to move little during dry periods, creating hotspots for ${ }^{15} \mathrm{~N}$ in the soil. The exceptionally high recoveries in the first organic layer at these sites were generally driven by only one of the 4-5 cores taken per plot, and removing these outliers from the analysis gave us more reasonable recovery (dotted lines in Fig. 2).

Nearly all ${ }^{15} \mathrm{~N}$ that remained in the plots between years 1 and 2 was found in the ground (the green layer and soil). As observed for short-term dynamics, the relatively recalcitrant soil-N pool (i.e., non-labile-N pool, or hydrolyzable-unknown $\mathrm{N}$ and non-hydrolyzable $\mathrm{N}$ combined) accounted for $>60 \%$ of ${ }^{15} \mathrm{~N}$ recovered in the first organic layer after 2 years (Fig. 9, Table 4). This, combined with the very small recovery in the vascular plants $\left(<6 \%\right.$ of added ${ }^{15} \mathrm{~N}$ in year 1 and $<1 \%$ in year 2, Table 5), indicates that very little of the added ${ }^{15} \mathrm{~N}$ had become available for uptake by vascular plants during the study period. The strong ${ }^{15} \mathrm{~N}$ retention by the green layer, which is above the rooting zone, and the incorporation of new $\mathrm{NH}_{4}{ }^{+}-\mathrm{N}$ into the relatively recalcitrant soil-N pool in the rooting zone may play a significant role limiting $\mathrm{N}$ availability to vascular plants in this ecosystem.

The greater contribution of non-labile $\mathrm{N}$ and amino acid (HAA) pools to ${ }^{15} \mathrm{~N}$ recovery relative to hydrolyzable- $\mathrm{NH}_{4}{ }^{+}$pool (Table 4) indicates turnover of microbial biomass and/or nonbiological stabilization as processes that incorporate ${ }^{15} \mathrm{~N}$ into recalcitrant soil $\mathrm{N}$. In a laboratory study, Knicker et al. (1997) found that $\mathrm{NH}_{4}{ }^{+}$added to organic residues was quickly assimilated into microbial biomass as peptides and amides and that these compounds were the major forms of recalcitrant soil N. Because proteinaceous compounds are generally chemically reactive, they react with soil organic matter to form recalcitrant N. In contrast, a number of studies have suggested that nonbiological condensation of phenolic or quinone structures with $\mathrm{NH}_{4}{ }^{+}$, amino acids, and proteins is one of the major mechanisms that form recalcitrant $\mathrm{N}$ in soils (studies summarized in Knicker 2004). Contrary to our expectations, the recovery of added ${ }^{15} \mathrm{~N}$ in the amino sugars (HAS) pool was low (Table 4). This may indicate that in our study, nonbiological immobilization is more important than turnover of microbial biomass. Alternatively, the low recovery in the HAS pool may be a result of relatively fast turnover of this pool. One recent study found a decline in HAS upon changes in land use (Zhang et al. 1999); in this study the cultivation of native grassland for $>80$ years reduced HAS concentration by $6 \%$, suggesting faster turnover of HAS pool relative to other $\mathrm{N}$-compounds in the soil.

\section{Hydrology and movement of dissolved $N$}

A conceptual model of the movement of ${ }^{15} \mathrm{~N}$ down the hillslope (Fig. 10) indicates that flux and flow path of water are a critical element that determines the magnitude of total ${ }^{15} \mathrm{~N}$ released from the green layer and soil in this tundra ecosystem. For example, when we estimated ${ }^{15} \mathrm{~N}$ released into downslope-flow water during the 2004 snowmelt (Fig. 10), the high ${ }^{15} \mathrm{~N}$ enrichment of dissolved-N pools at the Crest site was offset by the low water flux, whereas the smaller ${ }^{15} \mathrm{~N}$ enrichment at the Riparian site was accompanied by high water flux, resulting in an estimated total ${ }^{15} \mathrm{~N}$ release into the snowmelt water of as much as $\sim 20 \%$ of added (Fig. 8). Similarly, total ${ }^{15} \mathrm{~N}$ release into downslope-flow water was greater during the snowmelt than other seasons at all sites, it was greater at Riparian than other sites at all times, and it was greater at WT than NWT sites (Fig. 10). The high total ${ }^{15} \mathrm{~N}$ release 
during snowmelt occurs because (1) the snowmelt water exclusively flows through the thawed green layer where most ${ }^{15} \mathrm{~N}$ is retained, because most soil underneath it is still frozen at this time, (2) snowmelt water is highly concentrated with ions relative to rain water (up to three times higher concentration; Everett et al. [1996]), thus exchanging ${ }^{15} \mathrm{NH}_{4}^{+}$that was retained on the cationexchange sites of mosses in the green layer more efficiently than rain water, (3) any soluble-N compounds that have accumulated in the green layer over winter are subject to leaching at snowmelt, and (4) biological ${ }^{15} \mathrm{~N}$ immobilization and nonbiological sorption in the organic soil would be negligible because most of the organic soil and rooting zone is still frozen, although some microbial uptake within the thawed layer would be expected during the melt season (Brooks et al. 1998). The difference in the pattern of ${ }^{15} \mathrm{~N}$ enrichment of downslope-flow water between 2004 and 2006 may be attributed to the unusually thin snowpack, and thus less meltwater volume, in 2006.

${ }^{15} \mathrm{~N}$ enrichment in downslope-flow water declined with distance from the plots (Fig. 10). This decline is most likely caused by the addition of $\mathrm{N}$ from other sources, lowering the ${ }^{15} \mathrm{~N}:{ }^{14} \mathrm{~N}$ ratio of dissolved-N pool. Potential $\mathrm{N}$ inputs include $\mathrm{N}$ fixation, dissimilation, and $\mathrm{N}$ from the snowpack and melt water itself. However, because virtually no added ${ }^{15} \mathrm{~N}$ was lost from the Riparian and the two NWT sites throughout the study period even though as much as $21 \%$ of added ${ }^{15} \mathrm{~N}$ was released into downslope-flow water (Fig. 8), subsequent immobilization of released ${ }^{15} \mathrm{~N}$ must also be very high. Loss of ${ }^{15} \mathrm{~N}$ to deep soil via vertical leaching is unlikely at all but Crest sites because of shallow thaw depth especially during snowmelt or soilmelt.

We suspect that rapid biological and/or nonbiological immobilization combined with dilution of the label by the replenishment of the dissolved-N pool from dissimilation is most responsible for the decline of ${ }^{15} \mathrm{~N}$ enrichment in the downslope-flow water. As discussed in Discussion: Short-term dynamics, immobilization would remove both ${ }^{14} \mathrm{~N}$ and ${ }^{15} \mathrm{~N}$ proportionally, whereas dissimilation/export process would preferentially release ${ }^{14} \mathrm{~N}$. During snowmelt, dilution by incoming $\mathrm{N}$ at natural-abundance levels may have also contributed to the reduced ${ }^{15} \mathrm{~N}$ enrichment of the downslope-flow water.

Nitrogen fixation is unlikely to be very important in the decline of ${ }^{15} \mathrm{~N}$ enrichment in downslope-flow water, for the reasons discussed in Discussion: Long-term dynamics. Furthermore, the laboratory experiments of Hobara et al. (2006) suggest that fixation would be higher later in the year, during soilmelt, not snowmelt. If $\mathrm{N}$ fixation is important to ${ }^{15} \mathrm{~N}$ enrichment and the rates are higher during soilmelt, this would be inconsistent with the longer $95 \%$ depletion distance $\left(D_{0.95}\right)$ during soilmelt than snowmelt (Table 7).

Based on the total ${ }^{15} \mathrm{~N}$ recovered within the plot, the spatial and temporal variations of $D_{0.95}$ and of total ${ }^{15} \mathrm{~N}$ released into downslope-flow water, and differences in flow rates among topolocations and dates, the primary factors that determine leaching losses of added ${ }^{15} \mathrm{~N}$ are the magnitude of total ${ }^{15} \mathrm{~N}$ released into downslope-flow water, $\mathrm{N}$-immobilization capacity of the site, and flow rate of downslope-flow water. During snowmelt, mosses and detritus in the green layer may serve as both source and sink for dissolved ${ }^{15} \mathrm{~N}$, because at that time downslope-flow water flows through the green layer over frozen soil. Little loss of ${ }^{15} \mathrm{~N}$ from Riparian and two NWT sites despite high ${ }^{15} \mathrm{~N}$ release into downslopeflow water (Fig. 8) are possible because of the strong immobilization capacity of the green layer. In contrast, the long $D_{0.95}$ (Fig. 10, Table 7) observed during soilmelt suggests the lack of strong $\mathrm{N}$ sinks or slower dissimilation/export processes during this season than other seasons, or both. Downslope-flow water during soilmelt lacks full contact with the green layer, because the water flows below it within the upper soil, yet the depth of thaw is still shallow. Furthermore, the soilmelt period may correspond to transition from microbialbased $\mathrm{N}$ retention to plant-based retention (by root uptake). Brooks et al. (1998) found that in the alpine soils of Colorado, USA, the microbial-biomass-N pool peaked during the early stages of snowmelt and declined rapidly during the later melt season. Similarly, by yearround monitoring of alpine tundra soils for changes in soil-N pools as well as microbial biomass and activity, Lipson and Monson (1998) concluded that $\mathrm{N}$ was mostly immobilized in microbial biomass in early spring, whereas the plants were a stronger sink for $\mathrm{N}$ during the growing season. These asynchronies between the timing of $\mathrm{N}$ released into dissolved- $\mathrm{N}$ pool and the ability of the plants to take up $\mathrm{N}$ may contribute to the $\mathrm{N}$ limitation of plant production (Shaver et al. 1992). By characterizing DON of northern European boreal streams, Stepanauskas et al. (2000) found that up to $55 \%$ of DON leached from the terrestrial system during the spring flood was labile DON (urea and hydrolyzable amino acids), which can be taken up directly by some plants (Neff et al. 2003), whereas only $<28 \%$ was labile at post-spring base flow. These studies combined with our results suggest that terrestrial $\mathrm{N}$ in arctic and boreal regions may be susceptible to loss via leaching during spring melt.

Slow flow rate allows more time for ${ }^{15} \mathrm{~N}$ in the water to be immobilized, leading to little loss of added ${ }^{15} \mathrm{~N}$. The small $D_{0.95}$ for Riparian can be explained partly by a slower downslope-flow water because of the smaller topographic gradient at this site. Newbold et al. (1982) showed in their conceptual model that flow rate and flux of stream water was one of the factors that determine nutrient spiral length in stream ecosystems. In a simulation study, Rastetter et al. (2004) found that $\mathrm{N}$ movement on hillslopes was very slow (over 98\% of added $\mathrm{N}$ taken up in 2-5 $\mathrm{m}$ ), their estimated rate being equivalent to $D_{0.95}<2-5 \mathrm{~m}$. However, their simulations included only DIN, which was taken up rapidly by microbes and plants and was a minor component of 
total dissolved $\mathrm{N}$ in downslope-flow water (Table 6). Our longer transport distances $\left(D_{0.95}\right)$ are probably due to inclusion of DON in our sampling. Although Rastetter et al. (2004) used annual means and did not account for the large transport during snow and soilmelt periods, they did find that transport distances increased with the rate of water flowing downslope in agreement with our findings.

\section{CONCLUSION AND IMPLicATIONS}

Most ${ }^{15} \mathrm{NH}_{4}^{+}$added to the surface of tundra was retained tightly in the green layer at all sites. High ${ }^{15} \mathrm{~N}$ retention was due to the high immobilization in mosses and to direct immobilization into plant detritus. Once it reached the soil beneath the green layer, ${ }^{15} \mathrm{~N}$ was incorporated quickly into less labile pools that are unavailable for uptake by vascular plants. The green layer serves as the point of entry for most $\mathrm{N}$ inputs to this hillslope, as it efficiently captures atmospherically deposited $\mathrm{NH}_{4}^{+}$, and it is the primary location of $\mathrm{N}$ fixation (0-3 cm; Hobara et al. 2006). However, N cycling within the green layer is distinct from that of the soil beneath it, differing in both the forms and timing of $\mathrm{N}$ turnover, uptake, and immobilization. The $\mathrm{N}$ cycles in the green layer and in the soil beneath it are connected by vertical transport of dissolved $\mathrm{N}$ in infiltrating water only upon significant rain events during growing season. However, limited precipitation $(\sim 20 \mathrm{~cm})$ during the growing season likely constrains the connection between the two $\mathrm{N}$ cycles and may contribute further to the $\mathrm{N}$ limitation in this system. The N-release from the green layer (and from the system as a whole) occurs during snowmelt, when the most soil is still frozen and thus uptake by vascular plants is negligible. This asynchrony may lead to losses of dissolved $\mathrm{N}$ during late spring melt (soilmelt), contributing significantly to persistent $\mathrm{N}$ limitation in this arctic tundra ecosystem.

The $\mathrm{N}$ cycle in this arctic landscape may be greatly changed by the climatic warming that has occurred in the Alaskan Arctic over the last several decades (Serreze et al. 2000) and is expected to continue. In a warmer climate, dissimilation of recalcitrant $\mathrm{N}$ in the soil would be faster and more complete (i.e., the end products would be DIN and smaller organic compounds), resulting in higher $\mathrm{N}$ availability in the soil. Warmer climate has also extended the length of snow-free season in Alaska (Stone et al. 2002). This extended snow-free season and resulting deeper depth of thaw would allow more frequent vertical infiltration of water (because more precipitation events would be rain rather than snow), and may result in a greater flux of relatively labile $\mathrm{N}$ from the green layer to soil. The increased abundance of deciduous shrub species in non-shrub tundras in recent decades (Sturm et al. 2001) may be one of the best indications of increased $\mathrm{N}$ availability in the soil as shrubs respond strongly to fertilizer addition (Chapin et al. 1995). A longer snow-free season and higher summer temperature would also create more favorable conditions for wildfires, heretofore rare events north of the Brooks Range (C. Racine and R. Jandt, unpublished manuscript). Fire may remove the functionally unique green layer and dramatically alter $\mathrm{N}$ dynamics as well as surface microclimate and energy and $\mathrm{C}$ balance. Understanding the impacts of these expected changes in $\mathrm{N}$ dynamics and $\mathrm{N}$ availability in arctic tundra landscapes on global biogeochemical cycling remains a significant challenge for future research.

\section{ACKNOWLEDGMENTS}

We thank Brad Dewey, Bill Holmes, John Pastor, and Don Zak for analyses on CFN, SEDN, $\mathrm{N}_{\text {res}}$, and part of DIN; Marshall Otter for isotope analyses; and Donnie Bret-Hart, Kei Fujimura, Christie Haupert, George Kling, Jim Laundre, Carrie McCalley, Erica Stevie, and numerous fellow scientists, RAs, and students supported by NSF REU program for field and laboratory help. We also thank three anonymous reviewers for helpful comments on the manuscript. Funding was provided by NSF grant $\# 0444592$. Additional support was provided by the Arctic Long Term Ecological Research program, funded by the National Science Foundation, Division of Environmental Biology.

\section{Literature Cited}

Aerts, R., J. T. A. Verhoeven, and D. F. Whigham. 1999. Plantmediated controls on nutrient cycling in temperate fens and bogs. Ecology 80:2170-2181.

Alexander-Ozinskas, M. O. 2008. Denitrification contributes to nitrogen loss in fertilized arctic tundra sites. Thesis. Brown University, Providence, Rhode Island, USA.

Brookes, P. C., A. Landman, G. Pruden, and D. S. Jenkinson. 1985. Chloroform fumigation and the release of soil nitrogen: a rapid direct extraction method to measure microbial biomass nitrogen in soil. Soil Biology and Biochemistry 17: 837-842.

Brooks, P. D., J. M. Stark, B. B. McInteer, and T. Preston. 1989. Diffusion method to prepare soil extracts for automated nitrogen-15 analysis. Soil Science Society of America Journal 53:1707-1711.

Brooks, P. D., M. W. Williams, and S. K. Schmidt. 1998. Inorganic nitrogen and microbial biomass dynamics before and during spring snowmelt. Biogeochemistry 43:1-15.

Cabrera, M. L., and M. H. Beare. 1993. Alkaline persulfate oxidation for determining total nitrogen in microbial biomass extracts. Soil Science Society of America Journal 57:10071012.

Chapin, F. S., III, N. Fetcher, K. Kielland, K. Everett, and A. E. Linkins. 1988. Productivity and nutrient cycling of Alaskan tundra: enhancement by flowing soil water. Ecology 69:693-702.

Chapin, F. S., III, G. R. Shaver, A. E. Giblin, K. J. Nadelhoffer, and J. A. Laundre. 1995. Responses of arctic tundra to experimental and observed changes in climate. Ecology 76:694-711.

Clemmensen, K. E., P. L. Sorensen, A. Michelsen, S. Jonasson, and L. Ström. 2008. Site-dependent N uptake from N-form mixtures by arctic plants, soil microbes and ectomycorrhizal fungi. Oecologia 155:771-783.

Clymo, R. S. 1963. Ion exchange in Sphagnum and its relation to bog ecology. Annals of Botany 27:309-324.

Currie, W. S., K. J. Nadelhoffer, and J. D. Aber. 1999. Soil detrital processes controlling the movement of ${ }^{15} \mathrm{~N}$ tracers to forest vegetation. Ecological Applications 9:87-102. 
Dijkstra, P., A. Ishizu, R. R. Doucett, S. C. Hart, E. Schwartz, O. V. Menyailo, and B. A. Hungate. $2006 .{ }^{13} \mathrm{C}$ and ${ }^{15} \mathrm{~N}$ natural abundances of the soil microbial biomass. Soil Biology and Biochemistry 38:3257-3266.

Dijkstra, P., C. M. LaViolette, J. S. Coyle, R. R. Doucett, E. Schwartz, S. C. Hart, and B. A. Hungate. $2008 .{ }^{15} \mathrm{~N}$ enrichment as an integrator of the effects of $\mathrm{C}$ and $\mathrm{N}$ on microbial metabolism and ecosystem function. Ecological Letters 11:389-397.

Eckstein, R. L. 2000. Nitrogen retention by Hylocomium splendens in a subarctic birch woodland. Journal of Ecology 88:506-515.

Everett, K. R., D. L. Kane, and L. D. Hinzman. 1996. Surface water chemistry and hydrology of a small arctic drainage basin. Pages 185-201 in J. F. Reynolds and J. D. Tenhunen, editors. Landscape function and disturbance in arctic tundra, Ecological Studies 120. Springer-Verlag, Berlin, Germany.

Everett, K. R., G. M. Marion, and D. L. Kane. 1989. Seasonal geochemistry of an arctic tundra drainage basin. Holarctic Ecology 12:279-289.

Friedel, J. K., and E. Scheller. 2002. Composition of hydrolysable amino acids in soil organic matter and soil microbial biomass. Soil Biology and Biochemistry 34:315325.

Giblin, A. E., K. J. Nadelhoffer, G. R. Shaver, J. A. Laundre, and A. J. McKerrow. 1991. Biogeochemical diversity along a riverside toposequence in arctic Alaska. Ecological Monographs 61:415-435.

Hahn, S. C., S. F. Oberbauer, R. Geraier, N. E. Grulke, O. L. Lange, and J. D. Tenhunen. 1996. Vegetation structure and aboveground carbon and nutrient pools in the Imnavait Creek watershed. Pages 109-128 in J. F. Reynolds and J. D. Tenhunen, editors. Landscape function and disturbance in arctic tundra, Ecological Studies 120. Springer-Verlag, Berlin, Germany.

Hastings, S. J., S. A. Luchessa, W. C. Oechel, and J. D. Tenhunen. 1989. Standing biomass and production in water drainages of the foothills of the Philip Smith Mountains, Alaska. Holarctic Ecology 12:304-311.

Hinzman, L. D., D. L. Kane, C. S. Benson, and K. R. Everett. 1996. Energy balance and hydrological processes in an arctic watershed. Pages 131-154 in J. F. Reynolds and J. D. Tenhunen, editors. Landscape function and disturbance in arctic tundra, Ecological Studies 120. Springer-Verlag, Berlin, Germany.

Hobara, S., C. McCalley, K. Koba, A. E. Giblin, and G. R. Shaver. 2006. Nitrogen fixation in an arctic tundra watershed: a key atmospheric $\mathrm{N}$ source. Arctic, Antarctic, and Alpine Research 38:363-372.

Jonasson, S., A. Michelsen, and I. K. Schmidt. 1999. Coupling of nutrient cycling and carbon dynamics in the arctic, integration of soil microbial and plant processes. Applied Soil Ecology 11:135-146.

Kawahigashi, M., K. Kaiser, K. Kalbitz, A. Rodionov, and G. Guggenberger. 2004. Dissolved organic matter in small streams along a gradient from discontinuous to continuous permafrost. Global Change Biology 10:1576-1586.

Kerley, S. J., and J. D. Read. 1997. The biology of mycorrhiza in the Ericaceae. XIX. Fungal mycelium as a nitrogen source for the ericoid mycorrhizal fungus Hymenoscyphus ericae and its host plants. New Phytologist 136:691-701.

Knicker, H. 2004. Stabilization of N-compounds in soil and organic-matter-rich sediments - what is the difference? Marine Chemistry 92:167-195.

Knicker, H., H. D. Ludemann, and K. Haider. 1997. Incorporation studies of $\mathrm{NH}_{4}{ }^{+}$during incubation of organic residues by ${ }^{15} \mathrm{~N}$-CPMAS-NMR-spectroscopy. European Journal of Soil Science 48:431-441.

Kotanen, P. M. 2002. Fates of added nitrogen in freshwater arctic wetlands grazed by snow geese: the role of mosses. Arctic, Antarctic, and Alpine Research 34:219-255.
Kramer, M. G., P. Sollins, R. S. Sletten, and P. K. Swart. 2003. $\mathrm{N}$ isotope fractionation and measures of organic matter alteration during decomposition. Ecology 84:2021-2025.

Lajtha, K., W. M. Jarrell, D. W. Johnson, and P. Sollins. 1999. Collection of soil solution. Pages 166-82 in G. P. Robertson et al., editors. Standard soil methods for long-term ecological research. Oxford University Press, New York, New York, USA.

Li, Y., and D. H. Vitt. 1997. Patterns of retention and utilization of aerially deposited nitrogen in boreal peatlands. Ecoscience 4:106-116.

Lipson, D. A., and R. K. Monson. 1998. Plant-microbe competition for soil amino acids in the alpine tundra: effects of freeze-thaw and dry-rewet events. Oecologia 113:406-414.

Marion, G. M., P. C. Miller, and C. H. Black. 1987. Competition for tracer ${ }^{15} \mathrm{~N}$ in tussock tundra ecosystems. Holarctic Ecology 10:230-234.

Mulvaney, R. L., and S. A. Khan. 2001. Diffusion methods to determine different forms of nitrogen in soil hydrolysates. Soil Science Society of America Journal 65:1284-1292.

Myrold, D. D. 1998. Transformations of nitrogen. Pages 259294 in D. M. Sylvia et al., editors. Prentice-Hall, Upper Saddle River, New Jersey, USA.

Nadelhoffer, K. J., M. R. Downs, and B. Fry. 1999. Sinks for ${ }^{15} \mathrm{~N}$-enriched additions to an oak forest and a red pine plantation. Ecological Applications 9:72-86.

Nadelhoffer, K. J., A. E. Giblin, G. R. Shaver, and J. A. Laundre. 1991. Effects of temperature and substrate quality on element mineralization in six arctic soils. Ecology 72:242253.

Neff, J. C., F. S. Chapin, III, and P. M. Vitousek. 2003. Breaks in the cycle: dissolved organic nitrogen in terrestrial ecosystems. Frontiers in Ecology and the Environment 1: 205-211.

Newbold, J. D., R. V. O'Neill, J. W. Elwood, and W. van Winkle. 1982. Nutrients spiralling in streams: implications for nutrient limitation and invertebrate activity. American Naturalist 120:628-652.

Nordin, A., I. K. Schmidt, and G. R. Shaver. 2004. Nitrogen uptake by arctic soil microbes and plants in relation to soil nitrogen supply. Ecology 85:955-962.

Perakis, S. S., and L. O. Hedin. 2001. Fluxes and fates of nitrogen in soil of an unpolluted old-growth temperate forest, southern Chile. Ecology 82:2245-2260.

Perakis, S. S., and L. O. Hedin. 2002. Nitrogen loss from unpolluted South American forests mainly via dissolved organic compounds. Nature 415:416-419.

Press, M. C., and J. A. Lee. 1982. Nitrate reductase activity of Sphagnum species in the South Pennines. New Phytologist 92: 487-494.

Rastetter, E. B., B. L. Kwiatkowski, S. Le Dizes, and J. E. Hobbie. 2004. The role of down-slope water and nutrient fluxes in the response of Arctic hill slopes to climate change. Biogeochemistry 69:37-62.

Rastetter, E. B., S. S. Perakis, G. R. Shaver, and G. I. Ågren. 2005. Terrestrial $\mathrm{C}$ sequestration at elevated $\mathrm{CO}_{2}$ and temperature: the role of dissolved organic $\mathrm{N}$ loss. Ecological Applications 15:71-86.

Schimel, J. P., and F. S. Chapin, III. 1996. Tundra plant uptake of amino acid and $\mathrm{NH}_{4}{ }^{+}$nitrogen in situ: plants compete well for amino acid N. Ecology 77:2142-2147.

Schmidt, I. K., S. Jonasson, G. R. Shaver, A. Michelsen, and A. Nordin. 2002. Mineralization and distribution of nutrients in plants and microbes in four arctic ecosystems: responses to warming. Plant and Soil 242:93-106.

Serreze, M. C., J. E. Walsh, F. S. Chapin, III, T. Osterkamp, M. Dyurgerov, V. Romanovsky, W. C. Oechel, J. Morison, T. Zhang, and R. G. Barry. 2000. Observational evidence of recent change in the northern high latitude environment. Climate Change 46:159-207. 
Shaver, G. R., W. D. Billings, F. S. Chapin, III, A. E. Giblin, K. J. Nadelhoffer, W. C. Oechel, and E. B. Rastetter. 1992. Global change and the carbon balance of arctic ecosystems. BioScience 42:433-441.

Shaver, G. R., S. M. Bret-Harte, M. H. Jones, J. Johnstone, L. Gough, J. Laundre, and F. S. Chapin. 2001. Species composition interacts with fertilizer to control long-term change in tundra productivity. Ecology 82:3163-3181.

Shaver, G. R., and F. S. Chapin, III. 1991. Production/biomass relationships and element cycling in contrasting arctic vegetation types. Ecological Monographs 61:1-31.

Sigman, D. M., M. A. Altabet, R. Michener, D. C. McCorkle, B. Fry, and R. M. Holmes. 1997. Natural abundance-level measurement of the nitrogen isotopic composition of oceanic nitrate: an adaptation of the ammonia diffusion method. Marine Chemistry 57:277-242.

Solozano, L., and J. H. Sharp. 1980. Determination of total dissolved nitrogen in natural waters. Limnology and Oceanography 25:751-754.

Stepanauskas, R., H. Laudon, and N. O. G. Jørgensen. 2000. High DON bioavailability in boreal streams during a spring flood. Limnology and Oceanography 45:1289-1307.

Stone, R. S., E. G. Dutton, J. M. Harris, and D. Longnecker. 2002. Earlier spring snowmelt in northern Alaska as an indicator of climate change. Journal of Geophysical Research 107(D10):4089.

Sturm, M., C. Racine, and K. Tape. 2001. Increasing shrub abundance in the Arctic. Nature 411:546-547.
Thorn, K. A., and M. A. Mikita. 1992. Ammonia fixation by humic substances: a nitrogen-15 and carbon-13 NMR study. Science of the Total Environment 113:67-87.

Turetsky, M. R. 2003. The role of bryophytes in carbon and nitrogen cycling. Bryologist 106:395-409.

Vitousek, P. M., L. O. Hedin, P. A. Matson, J. H. Fownes, and J. Neff. 1998. Within-system element cycles, input-output budgets, and nutrient limitation. Pages $432-451$ in M. L. Pace and P. M. Groffman, editors. Successes, limitations, and frontiers in ecosystem science. Springer-Verlag, New York, New York, USA.

Walker, D. A., and M. D. Walker. 1996. Terrain and vegetation of the Imnavait Creek watershed. Pages 73-108 in J. F. Reynolds and J. D. Tenhunen, editors. Landscape function and disturbance in arctic tundra, Ecological Studies 120. Springer-Verlag, Berlin, Germany.

Weintraub, M. N., and J. P. Schimel. 2005. The seasonal dynamics of amino acids and other nutrients in Alaskan Arctic tundra soils. Biogeochemistry 73:359-380.

Zang, X., J. D. H. van Heemst, K. J. Dria, and P. G. Hatcher. 2000. Encapsulation of protein in humic acid from a histosol as an explanation for the occurrence of organic nitrogen in soil and sediment. Organic Geochemistry 31:679-695.

Zhang, X., W. Amelung, Y. Yuan, S. Samson-Liebig, L. Brown, and W. Zech. 1999. Land-use effects on amino sugars in particle size fractions of an Argiudoll. Applied Soil Ecology 11:271-275.

\section{APPENDIX}

Descriptions of soil layers and their properties by site (Ecological Archives M080-011-A1). 